From: Hames, W.E., McHone, G.C., Renne, P.R., and Ruppel, C., eds., The Central Atlantic Magmatic Province, American Geophysical Union Monograph, 2002, in press.

\title{
Relative Timing of CAMP, Rifting, Continental Breakup, and Basin Inversion: Tectonic Significance
}

\author{
Roy W. Schlische and Martha Oliver Withjack \\ Department of Geological Sciences, Rutgers University, Piscataway, New Jersey \\ Paul E. Olsen \\ Department of Earth and Environmental Sciences and Lamont-Doherty Earth Observatory of \\ Columbia University, Palisades, New York
}

\begin{abstract}
Short-duration CAMP magmatic activity at 200 Ma in eastern North America provides a temporal benchmark for assessing the relative timing of rifting, drifting, and basin inversion. In the southeastern United States, rifting ceased and shortening/inversion began before CAMP magmatism. In the northeastern United States and southeastern Canada, rifting continued during and after CAMP magmatism. Rifting ceased in the northeastern United States and southeastern Canada by the early Middle Jurassic, after CAMP magmatic activity. Shortening/inversion occurred in southeastern Canada before or during the Early Cretaceous. The available geological, geophysical, and geochronological data favor a diachronous rift-drift transition (seafloor spreading began earlier in the south) rather than the traditional synchronous rift-drift transition along the entire central North Atlantic margin. In this scenario, there are two magmatic pulses. The first includes CAMP and the formation of seaward-dipping reflectors (SDR's) near the continent-ocean boundary during the rift-drift transition along the southern margin segment. The second, younger magmatic pulse is associated with the formation of SDR's during the rift-drift transition along the northern margin segment. We believe that the widespread magmatism and shortening/inversion in eastern North America are related to active asthenospheric upwelling that culminated during the rift-drift transition. Inversion is a common feature along many volcanic passive margins and is associated with a change in the strain state from extension at a high angle to the margin during rifting to shortening at a high angle to the margin during drifting. The presence of dikes oriented at a high angle to the trend of the margin (e.g., the dike swarms in the southeastern United States, southeastern Greenland, offshore northwest Europe, and South America) may reflect this change in strain state associated with inversion.
\end{abstract}

\section{INTRODUCTION}

The Mesozoic rift system and passive margin of eastern North America (Figure 1) are arguably the best exposed and best studied of the rift systems and passive margins that formed during the progressive (diachronous) breakup of Pangea [e.g., Dietz and Holden, 1970]. The rift system and passive margin provide a natural laboratory for studying the extensional structures and rift basins associated with continental rifting, breakup, and initiation of seafloor spreading [e.g., Manspeizer, 1988; Sheridan and Grow, 1988; Schlische, 1993; Withjack et al., 1998; Schlische, 2002]. The early Mesozoic is also a critical period in Earth history, as the Triassic-Jurassic boundary marks the second largest mass extinction [e.g., Sepkowski, 1997] and is associated with one of the largest (at least in terms of area) large-igneous 
provinces (LIP's) in the world [e.g., McHone, 1996, 2000; Marzolli et al., 1999; Olsen, 1999]. The Central Atlantic Magmatic Province (CAMP) includes flood basalts, dikes, and associated intrusive sheets generally dated at about $200 \mathrm{Ma}$ [e.g., Olsen et al., 1996b; Olsen, 1999]. The eastern North American passive margin is also host to volcanic/volcaniclastic wedges (seaward-dipping reflectors, SDR's) [e.g., Sheridan et al., 1993; Holbrook and Kelemen, 1993; Oh et al., 1995; Talwani et al., 1995] that make it a volcanic passive margin, although the exact temporal relationships between CAMP and the SDR's are not yet clear.

In recent years, a growing body of evidence indicates that the tectonic history of the eastern North American rift system and passive margin is not as simple as previously thought. Withjack et al. [1995, 1998] drew attention to a phase of contractional deformation and basin inversion that occurred during and/or shortly after the rift-drift transition. Although postrift contractional deformation has long been recognized in the Mesozoic rift system [e.g., Shaler and Woodworth, 1899; Sanders, 1963; deBoer and Clifton, 1988; Wise, 1993], the structures documented by Withjack et al. [1995, 1998] are much more widespread and represent much more shortening than previously reported. More importantly, Withjack et al. [1998] proposed that the initiation of postrift contractional deformation and basin inversion was diachronous along the central North American margin. Rifting ended and postrift deformation began earlier in the south than in the north. Withjack et al. [1998] hypothesized that the postrift contractional deformation is associated with processes occurring during the rift-drift transition. This has two important implications: 1 . If the initiation of postrift contractional deformation and basin inversion is diachronous along the margin, then the initiation of seafloor spreading is also diachronous. 2. The causes of inversion may be temporally and causally related to the processes contributing to the formation of SDR's at the rift-drift transition.

This paper explores the early Mesozoic tectonic history of eastern North America for the region between Georgia and Nova Scotia. We first review basic concepts regarding the tectonic history of eastern North America and define key terminology. We then describe critical geological and geophysical data and observations from eastern North America regarding CAMP, the initiation and cessation of rifting, the initiation of postrift deformation and basin inversion, and the initiation of seafloor spreading; this section updates and extends the findings of Withjack et al. [1998]. We then discuss two possible interpre- tations of these geological and geophysical data, the possible relationship between inversion and a Middle Jurassic hydrothermal event, and uncertainties regarding the shortening direction. We tentatively apply our model to other passive margins, and discuss the causes of inversion in passive-margin settings.

\section{BASIC CONCEPTS AND DEFINITIONS}

The eastern North American rift system (Figure 1), which formed as a result of the continental extension preceding the separation of North America and Africa, consists of a series of exposed and buried rift basins that extends from the southeastern United States to the region of the Grand Banks, Canada [e.g., Olsen, 1997]. The exclusively continental strata and lava flows that fill the exposed basins are collectively known as the Newark Supergroup (Figure 2) [Froelich and Olsen, 1984]. We divide the rift system into a northern segment and a southern segment. The diffuse boundary between the two segments separates rift basins containing Early Jurassic-age strata (northern segment) from those lacking Early Jurassic-age strata (southern segment) (Figure 2). Offshore, the Blake Spur magnetic anomaly dies out to the north and the East Coast magnetic anomaly shifts to the east in the boundary region (Figure 1).

The basins of the eastern North American rift system are mostly half graben bounded by predominantly normal-slip border faults, although some basins or subbasins are bounded by oblique-slip faults [e.g., Manspeizer, 1988; Olsen and Schlische, 1990; Schlische, 1993, 2002] (Figure 3 ). The rocks within and surrounding the rift basins may be subdivided into prerift, synrift, and postrift units. Prerift rocks were present prior to the start of basin subsidence, and include Precambrian basement and mildly to strongly deformed Paleozoic sedimentary and metasedimentary units. These rocks were deformed in the Appalachian orogenies preceding the assembly of Pangea, and many of the border faults of the rift basins are reactivated Paleozoic structures [e.g., Lindholm, 1978; Swanson, 1986; Ratcliffe and Burton, 1985; Ratcliffe et al., 1986]. Synrift units are rocks that accumulated while the basins were actively subsiding. These units generally dip and thicken toward the border fault and display a progressive decrease in dip upsection, thereby defining a wedgeshaped unit. Coarse-grained facies may be present in synrift strata immediately adjacent to the border-fault system. Postrift units accumulated after the end of faultcontrolled subsidence during thermal subsidence following breakup.

Although controversy surrounds the precise definition of basin inversion [Williams et al., 1989], it is generally agreed that a reversal in the deformational style produces inversion structures. Specifically, an extensional phase 
followed by a contractional phase creates positive inversion structures. Basin inversion occurs on active margins [e.g., de Graciansky et al., 1989; Letouzey, 1990; Ginger et al., 1993] and passive margins [e.g., Malcolm et al., 1991; Hill et al., 1995; Doré and Lundin, 1996; Vågnes et al., 1998; Withjack and Eisenstadt, 1999]. The above field and seismic studies, combined with experimental analysis [e.g., Buchanan and McClay, 1991; Mitra and Islam, 1994; Eisenstadt and Withjack, 1995; Keller and McClay, 1995; Brun and Nalpas, 1996], show that typical inversion structures include normal faults reactivated as reverse faults, newly formed reverse and thrust faults, monoclines, anticlines, and synclines (Figure 4). The term "postrift contractional structure" refers to those structures that did not have an earlier extensional deformational phase or for which the pre-contractional history is unclear or unknown. For the sake of brevity, we refer to all contractional structures as inversion structures unless there is definitive evidence that the structure did not undergo older extensional deformation.

Because eastern North America has undergone at least three phases of deformation (Paleozoic orogeny, early Mesozoic rifting, and inversion), it is not always straightforward to constrain the timing of deformation. Cross-cutting relationships can be used to determine the relative sequence of deformation. In addition, the presence or absence of growth features can be used to determine the absolute age of deformation. For example, strata that thicken into the troughs of synclines and thin onto the crests of anticlines indicate that these folds formed at the same time as the growth strata. Alternatively, strata whose thickness is unaffected by folds indicate that the folds post-date the deposition of the strata, although the absolute age of the deformation is unconstrained unless the fold is overlapped by undeformed strata. Cross-cutting relationships between extensional and inversion structures and CAMP-related dikes as well as growth geometries involving CAMP are particularly useful because CAMP magmatism is well dated and of short duration.

\section{CAMP AS A TEMPORAL BENCHMARK}

Our understanding of the age and duration of riftrelated magmatism has been continually refined over the last two decades [e.g., Sutter, 1988; Olsen et al., 1989, 1996b; Hames et al., 2000], as isotopic dating methods have improved and innovative stratigraphic methods have been employed. The igneous rocks of the Newark basin provide the best constraints on the age and duration of earliest Jurassic magmatism.
Here, core and outcrop studies [Fedosh and Smoot, 1998; Olsen et al., 1996a, b] show that three quartz-normative lava-flow sequences are interbedded with cyclical lacustrine strata. Based on Milankovitch cyclostratigraphy, the oldest lava is $20-40 \mathrm{kyr}$ younger than the palynologically defined Triassic-Jurassic boundary [e.g., Fowell et al., 1994]. Milankovitch cyclostratigraphy also constrains the duration of the igneous episode (base of the oldest lava flow to top of youngest flow) to $580 \pm 100 \mathrm{kyr}$ [Olsen et $a l ., 1996 \mathrm{~b}]$. The absolute age of the igneous rocks, 200 $\mathrm{Ma}$, is based on isotopic dating of the lava flows [Hames et al., 2000] and the Palisades intrusive sheet [Sutter, 1988; Dunning and Hodych, 1990; Turrin, 2000], which is physically connected to one of the flows [Ratcliffe, 1988]. The age and duration of the earliest Jurassic magmatic episode also apply to the Culpeper, Hartford, and Deerfield basins, based on almost exact match in cyclostratigraphy [e.g., Olsen et al., 1989; 1996b], basalt geochemistry [e.g., Tollo and Gottfried, 1992] (Figure 2b), and paleomagnetic signature [Prevot and McWilliams, 1989; Hozik, 1992]. In the Fundy basin, the North Mountain Basalt is isotopically dated at $\sim 200 \mathrm{Ma}[\mathrm{Ho}-$ dych and Dunning, 1992]. Furthermore, all extrusive lava flows and interbedded strata are normally magnetized [Witte et al., 1991; Kent et al., 1995].

The age and duration for the extrusive rocks discussed above also apply to most of the early Mesozoic intrusive rocks in the northern segment (see Figure 1) of the eastern North American rift system [Olsen et al., 1996b], for the following reasons: 1 . Nearly all intrusive igneous rocks (sills, sheets, generally NE-trending dikes) (Figures 5a, 6) belong to the same geochemical categories (all quartznormative) as the flows [e.g., Puffer and Philpotts, 1988; McHone, 1996]. 2. In some cases, intrusives served as feeders to the flows, as in the Newark basin [Ratcliffe, 1988]. In the Hartford basin, three NE-trending diabase dike swarms served as feeders for the three lava-flow sequences [Philpotts and Martello, 1986]. 3. Isotopic dates for diabase sheets in the Gettysburg basin are very similar to the Palisades sill [Sutter, 1988; Dunning and Hodych, 1990]. The Shelburne dike, located near the Fundy basin, is isotopically dated at $200 \mathrm{Ma}$ [Dunn et al., 1998]. 4. No tholeiitic intrusions cut strata younger than the youngest flow in a basin [e.g., Olsen et al., 1989]. Therefore, we are confident that the CAMP flows and intrusives in the northern segment of the rift system were emplaced in less than 1 million years at $\sim 200 \mathrm{Ma}$.

The situation is not as well defined in the southern segment of the rift system (see Figure 1). There are no Early Jurassic flows in the exposed rift basins [e.g., Olsen, 1997] (Figure 2a). However, interbedded olivineand quartz-normative flows are present in the subsurface of South Carolina and Georgia [Behrendt et al., 1981; Hamilton et al., 1983; McBride et al., 1989]. The flows 
are flat lying whereas rift strata are dipping, suggesting that the flows developed after rifting. Isotopic ages for these postrift flows span the interval 97-217 Ma, but none are considered reliable [e.g., Lamphere, 1983; Ragland, 1991]. Although the wider compositional range of these flows may suggest a longer temporal duration of magmatic activity, the olivinenormative compositions may be due to alteration [P. Ragland, personal communication, in Olsen et al., 1996b]. Alternating magnetic polarity zones for these flows [Phillips, 1983] also suggest a longer duration than for the northern-segment magmatism, but the paleomagnetic results may be unreliable [J. Phillips, personal communication, in Olsen et al., 1996b]. Intrusions in the southern segment of the rift system include abundant dikes and subsurface sills. The dikes fall into two groups: NW-trending (mostly olivine normative) and $\mathrm{N}$-trending dikes (mostly quartz-normative) [e.g., Ragland et al., 1983, 1992] (Figure 6). All NW-trending dikes are of normal polarity, and at least one N-trending dike is of reversed polarity [Smith, 1987]. Ragland et al. [1992] believed that both dike sets are $200 \mathrm{Ma}$, although the N-trending dikes appear to be slightly younger than the NW-trending dikes based on rare crosscutting relationships. Recent $\mathrm{Ar}^{40} / \mathrm{Ar}^{39}$ ages for two of the NW-trending dikes in South Carolina are 200 Ma [Hames et al., 2000]. In summary, the NWtrending dikes in the southern segment of the rift system appear to have the same age as the CAMP flows and intrusives in the northern segment of the rift system; however, the age of the $\mathrm{N}$-trending dikes and the postrift basalt flows is not as well constrained.

\section{STRUCTURAL GEOLOGY}

\subsection{Extensional Structures}

Synrift extensional structures are reviewed by Schlische [1993, 2002] and Withjack et al. [1998]. Briefly, the largest-scale extensional structures are scoop-shaped half-graben produced by faultdisplacement folding [Schlische, 1995; Withjack et al., 2002] (Figure 3). In cross section perpendicular to the border fault, the basin consists of a broad downfold that results because displacement progressively decreases away from the fault. In cross section parallel to the border fault, the basin consists of a broad syncline that results because displacement is greatest at the center of the border fault and progressively decreases toward the fault tips. Seismic, outcrop, and drill hole data indicate that these large-scale folds are growth folds. Smaller-scale structures include mostly NE-striking intrabasinal normal faults and transverse fault-displacement folds related to segmentation and/or undulations on the border fault. At least in the Newark basin, these folds began to form during synrift sedimentation. Commonly, the idealized geometry shown in Figure 3 is modified by large-scale basin segmentation, significant strike slip along the border-fault system, and postrift inversion.

\subsection{Inversion Structures}

Almost all of the large exposed basins in eastern North America contain inversion structures (see Withjack et al. [1995], and reviews by Withjack et al. [1998], and Schlische [2002]). The most notable structures are: (1) broad NE-trending anticlines developed in the hanging walls of gently dipping, NE-striking border faults of the Fundy subbasin of the Fundy rift basin [Withjack et al., 1995] (Figures 7b, 8a); (2) tight ENE- to E-trending synclines and anticlines formed in proximity to the steeply dipping ENE- to E-striking border faults of the Minas subbasin of the Fundy rift basin [Withjack et al., 1995] (Figures 7b, 8c); (3) generally NE-striking basementinvolved reverse faults and associated folds in the Richmond basin [Shaler and Woodworth, 1898; Venkatakrishnan and Lutz, 1988] (Figures 9a, b); (4) generally NEtrending inversion folds developed above NE-striking intrabasinal faults of the Taylorsville basin [LeTourneau, 1999] (Figure 9c); and (5) WNW-striking axial planar cleavage in some WNW-trending folds in the Newark basin [e.g., Lucas et al., 1988].

Inversion, by elevating the center of a rift basin relative to its margins, may have contributed to substantial erosion of these rift basins. For example, the center of the Minas subbasin has been uplifted relative to its margins [Withjack et al., 1995] (Figure 8d). The Taylorsville basin has undergone $0.9-2.6 \mathrm{~km}$ of erosion, with the largest amount occurring over inversion-related anticlines [Malinconico, 2002] (Figure 9c). The Newark basin has also undergone 2 to 5+ km of erosion [e.g., Pratt et al., 1988; Steckler et al., 1993; Malinconico, 1999] that may, in part, be related to inversion. Inversion may also be responsible for some of the anomalously high stratal dips recorded in many of the exposed rift basins. Experimental clay models [Eisenstadt and Withjack, 1995] indicate that low $\left(<10^{\circ}\right)$ synrift stratal dips develop during low to moderate amounts of extension, but that these dips may steepen appreciably during inversion (Figure 4c). The Danville rift basin contains steeply dipping beds $\left(\sim 45^{\circ}\right)$ that may have resulted from inversion (Figure 10b). The basin also contains small-scale reverse faults [Ackermann et al., 2002]. The Danville basin is also exceptionally narrow relative to its length. The narrow width is probably related to ero- 
sion associated with uplift.

\section{RELATIONSHIPS AMONG RIFTING, INITIA- TION OF INVERSION, AND CAMP}

\subsection{CAMP Basalts, Rift Basins, and the Diachro- nous End of Rifting}

Synrift CAMP basalt flows and related Early Jurassic-age strata are found only in rift basins in the northern segment of the central Atlantic margin [e.g., Olsen et al., 1989; Olsen, 1997] (Figures 1, 2a). Structural and stratigraphic data indicate that the northern-segment rift basins were active during this time (Early Jurassic). In the Newark basin, alluvialfan conglomeratic facies are present in strata interbedded with and succeeding the lava flows, and some of these units contain clasts of basalt [e.g., Manspeizer, 1980; Parker et al., 1988]. In the Connecticut Valley basin (Figure 10a), the basalt flows and interbedded strata are thickest adjacent to the border-fault system and thin toward the intrabasin high between the Hartford and Deerfield subbasins [e.g., LeTourneau and McDonald, 1988]. In the Fundy basin, outcrop, drill-hole, and seismic data indicate that the Late Triassic- and Early Jurassic-age synrift units generally thicken from the hinged margin of the basin toward the border-fault system [e.g., Olsen et al., 1989; Withjack et al., 1995] (Figure 7d, $8 \mathrm{a}, 8 \mathrm{c}, 8 \mathrm{~d}$ ). In addition, the sedimentary unit above the North Mountain Basalt, the McCoy Brook Formation, contains paleo-talus slope deposits composed predominantly of basalt clasts, indicating active faultcontrolled subsidence along the oblique-slip borderfault system [Olsen and Schlische, 1990; Tanner and Hubert, 1991] (Figure 8d). In the Newark basin, accumulation rates for earliest Jurassic-age strata are 25 times higher than for latest Triassic-age strata [e.g., Olsen et al., 1989; Schlische and Olsen, 1990]. A plot of cumulative stratigraphic thickness versus age for the northern-segment rift basins shows a pronounced steepening in the curves in earliest Jurassic time (Figure 2c).

The conditions in the southern-segment rift basins (Figure 1) were notably different. Early Jurassic-age strata are absent from all of the southern basins (Figure 2a). In fact, the youngest preserved Late Triassic-age strata in any of these basins (found in the Taylorsville basin) are $\sim 10 \mathrm{Myr}$ older than the Triassic-Jurassic boundary. Erosion and/or non-deposition may account for the absence of these deposits. Modeling studies based on thermal maturation indices [Malinconico, 2002] and fission-track analyses
[Tseng et al., 1996] in the Taylorsville basin indicate that, although more strata accumulated in this basin than is currently preserved, synrift subsidence most likely ceased close to the Triassic-Jurassic boundary. If these results are applicable to other southern-segment basins, then synrift subsidence ceased in the south prior to earliest Jurassic time while it continued in the north into Early Jurassic time. In fact, the northern-segment basins underwent accelerated subsidence during this time.

\subsection{Different State of Stress in Southern and Northern Rift Segments During CAMP}

The Mesozoic dikes in eastern North America do not have a uniform orientation [e.g., King, 1971; May, 1971] (Figures 5a, 6). An interpreted radial pattern [May, 1971] has been attributed to doming related to a mantle plume [e.g., Hill, 1991]. However, as discussed by McHone $[1988,2000]$, the dikes in eastern North America fall into several partially overlapping sets that have a fairly uniform orientation within each set. In the northern rift segment, the dikes are generally NE trending. In the southern rift segment, the dikes fall into two sets, a NWtrending set and slightly younger $\mathrm{N}$-trending set. These dikes cut uniformly across synrift and prerift rocks, indicating little or no influence of preexisting structures on dike orientations. Thus, the northern and southern rift segments experienced different states of stress during CAMP magmatism. In the northern segment, the maximum horizontal stress $\left(\mathrm{S}_{\mathrm{Hmax}}\right)$ was oriented NE-SW, and the minimum horizontal stress $\left(\mathrm{S}_{\mathrm{Hmin}}\right)$ was oriented NWSE. In the southern segment, $\mathrm{S}_{\mathrm{Hmax}}$ was NW-SE and $\mathrm{S}_{\mathrm{Hmin}}$ was NE-SW. The younger N-trending dike set indicates that $\mathrm{S}_{\mathrm{H} \max }$ was N-S and $\mathrm{S}_{\mathrm{Hmin}}$ was E-W. Thus, the state of stress was different for the northern and southern rift segments during CAMP magmatism, and it changed between the emplacement of the NW-trending set and the younger $\mathrm{N}$-trending set in the southern rift segment. Because the boundary between the northern and southern segments probably was diffuse (see section 2), the state of stress should have been transitional between NE-SWoriented $\mathrm{S}_{\mathrm{Hmin}}$ in the south and NW-SE-oriented $\mathrm{S}_{\mathrm{Hmin}}$ in the north. In fact, dikes in the transitional region (the area near the Culpeper and Gettysburg basins) trend $\sim \mathrm{N}-\mathrm{S}$, indicating that $\mathrm{S}_{\mathrm{H} \text { min }}$ was oriented $\sim \mathrm{E}-\mathrm{W}$.

The Early Jurassic stress state in the northern rift segment ( $\mathrm{S}_{\mathrm{H} \min }$ oriented NW-SE) is consistent with continued NW-SE extension, normal faulting, and basin subsidence in this region (Figures 3a, 6, 10a). However, the stress state in the southern rift segment $\left(\mathrm{S}_{\mathrm{Hmin}}\right.$ oriented NE-SW) is incompatible with NW-SE extension, normal faulting, and basin subsidence (Figures 6, 9a, 10b). Both dike sets in the southern rift segment cut across the rift basins and their bounding faults at a high angle [e.g., Ragland et al., 
1992]. These results corroborate the major conclusion from Section 5.1 that NW-SE extension, faulting, and subsidence had ceased in the southern segment prior to earliest Jurassic time while it continued in the northern segment [Withjack et al., 1998].

\subsection{Diachronous Initiation of Inversion}

All results for the southern segment of the rift system indicate that NW-SE extension had ceased prior to CAMP time, and that NW-SE to N-S shortening was taking place before, during, and after CAMP time [Withjack et al., 1998]. In the Richmond basin, NW-trending dikes cut a series of NNE-trending folds and reverse faults [Venkatakrishnan and Lutz, 1988], suggesting that NW-SE shortening began before and continued during CAMP time (Figure 9a). As mentioned in Section 3, postrift basalts are present in the subsurface of the southeastern United States [e.g., Behrendt et al., 1981; Hamilton et al., 1983; McBride et al., 1989]. Locally, these postrift basalts are deformed by contractional structures. For example, the NE-striking Cooke fault in South Carolina underwent at least $140 \mathrm{~m}$ of reverse displacement prior to the emplacement of the postrift basalt and had continued reverse displacement after the emplacement of the postrift basalt [Behrendt et al., 1981; Hamilton et al., 1983] (Figure 11e). If these basalts are CAMP basalts, then they provide additional evidence that rifting ended and inversion began prior to earliest Jurassic time along the southern segment of the central Atlantic margin.

All inversion structures in the northern segment rift basins are post-CAMP and also post-date the youngest preserved synrift deposits [Withjack et al., 1995, 1998]. For example, in the Fundy basin, seismic reflection profiles show that Triassic and Early Jurassic-age units thicken toward border faults but exhibit no thickening or thinning toward the hinges of inversion-related folds (Figure 8c). Inversion therefore post-dates the Early Jurassic-age North Mountain Basalt (CAMP) and overlying McCoy Brook Formation. Without the presence of younger Jurassic, Cretaceous, and Tertiary strata, it is impossible to further constrain the timing of the inversion in the Fundy basin. Information from the adjacent Orpheus graben, however, can provide this information. The Cobequid-Chedabucto fault system bounds the Minas subbasin and its offshore continuation, the Orpheus graben, on the north (Figure 1). If the faults bounding the Minas subbasin had a component of reverse movement during inversion, then the faults bounding the kinematically linked Orpheus graben likely experienced similar movements. Previous studies have shown that, except for regional subsidence and minor salt movement, structural activity in the Orpheus graben ceased during Early Cretaceous time [Tankard and Welsink, 1989; Wade and MacLean, 1990; MacLean and Wade, 1992]. Thus, any inversion in the Orpheus graben and, by inference, in the Fundy basin occurred before or during Early Cretaceous time.

Although the duration of inversion is not known, it is clear that inversion began earlier in the southern rift segment than for the northern rift segment. In the southern segment, inversion occurred prior to and continued through CAMP time. In the northern segment, inversion began not only after CAMP time but after the deposition of all Early Jurassic-age synrift strata. Thus, not only is the end of rifting diachronous from south to north but the initiation of inversion is diachronous from south to north.

\subsection{Initiation of Seafloor Spreading and Formation of SDR's}

Conventionally, continental breakup and the onset of seafloor spreading are thought to have begun in Middle Jurassic time along the entire central Atlantic margin [e.g., Klitgord and Schouten, 1986]. However, this estimate is subject to considerable uncertainty because the oldest oceanic crust does not contain identifiable and/or dated magnetic anomalies. In their calculations of the breakup age, Klitgord and Schouten [1986] assumed that the half-spreading rates of the Late Jurassic (19 mm/yr) also applied to earlier times. If spreading rates during earlier times were slower, however, then seafloor spreading would have initiated earlier. In fact, a half-spreading rate of $4 \mathrm{~mm} / \mathrm{yr}$ yields a breakup age of $\sim 200 \mathrm{Ma}$.

A massive wedge, presumably composed of volcanic or volcaniclastic rocks, is present along the edge of much of the central Atlantic margin [Hinz, 1981; Benson and Doyle, 1988; Klitgord et al., 1988; Austin et al., 1990; Holbrook and Keleman, 1993, Sheridan et al., 1993; Keleman and Holbrook, 1995; Oh et al., 1995] (Figures $11 \mathrm{a}, \mathrm{b}, \mathrm{c})$. The wedge lies near the continent-ocean boundary, and formed during the transition from rifting to drifting [Hinz, 1981; Benson and Doyle, 1988; Austin et al., 1990]. A wedge is not observed on the passive margin of southeastern Canada [Keen and Potter, 1995]. The exact age of the wedge (and, by inference, the onset of seafloor spreading) is unknown and, in fact, may vary along the margin [e.g., Oh et al., 1995]. Beneath the Georges Bank basin, SDR's within the wedge underlie a relatively flat-lying Middle Jurassic postrift sequence [Schlee and Klitgord, 1988]. Thus, the wedge beneath the Georges Bank basin formed before the Middle Jurassic deposition of these postrift strata. Beneath the Baltimore Canyon trough, SDR's overlap rift basins [Benson and Doyle, 1988] and underlie the postrift unconformity 
[Sheridan et al., 1993]. Thus, the wedge beneath the Baltimore Canyon trough formed after the deposition of the Late Triassic to Early Jurassic-age synrift strata and before the deposition of the thick package of postrift strata beneath the Late Jurassic-age rocks sampled in offshore wells [Poag and Valentine, 1988]. Beneath the Carolina trough, SDR's appear to underlie the postrift basalts [Austin et al., 1990; Oh et al., 1995]. If so, then the wedge beneath the Carolina trough formed before the eruption of the postrift basalts. If these postrift basalts belong to CAMP, then it is possible that the SDR's in this region are also associated with CAMP.

\section{DISCUSSION}

\subsection{Summary of Geological and Geophysical Data}

1. The CAMP flows and intrusives in the northern segment of the rift system were emplaced in less than 1 million years at $\sim 200 \mathrm{Ma}$ (earliest Jurassic time). The NW-trending dikes in the southern segment of the rift system have the same age as the CAMP flows and intrusives in the northern segment of the rift system. It is possible, however, that the emplacement of the postrift basalts and some of the other intrusives in the southern segment of the rift system occurred shortly before, during, or shortly after CAMP magmatism.

2. Synrift subsidence ceased in the southern segment of the rift system prior to earliest Jurassic time. It continued, however, in the northern segment of the rift system into Early Jurassic time. In fact, the rift basins in the northern segment underwent accelerated subsidence during earliest Jurassic time.

3. During earliest Jurassic time, the stress state indicated by dike trends $\left(\mathrm{S}_{\mathrm{Hmin}}\right.$ oriented NW-SE) in the northern segment of the rift system is compatible with continued NW-SE extension, normal faulting, and basin subsidence. The stress state indicated by dike trends $\left(\mathrm{S}_{\mathrm{Hmin}}\right.$ oriented NE-SW) in the southern segment of the rift system, however, is incompatible with NW-SE extension, normal faulting, and basin subsidence.

4. Inversion began earlier in the southern segment of the rift system than in the northern segment. In the southern segment, inversion occurred prior to and continued through CAMP time. In the northern segment, inversion began not only after CAMP time but after the deposition of all Early Jurassic-age synrift strata.

5. The formation of SDR's and the onset of seafloor spreading in the northern segment of the rift system occurred after the deposition of the Early Jurassicage synrift strata and before the deposition of the Early to Middle Jurassic-age postrift strata. The formation of the SDR's and the onset of seafloor spreading in the southern segment of the rift system occurred after the deposition of the Late Triassic-age synrift strata and before the deposition of the thick sedimentary wedge below sampled Late Jurassic-age postrift strata.

\subsection{Interpretations}

Two end-member scenarios can honor these available geological and geophysical observations. In scenario 1 (traditional scenario), the initiation of seafloor spreading was synchronous along the entire margin of the central North Atlantic Ocean during the late Early Jurassic to early Middle Jurassic. With this scenario, all of the SDR's on the margin of eastern North America are the same age (i.e., late Early Jurassic to early Middle Jurassic). Thus, with this scenario, two distinct episodes of magmatism affected eastern North America: CAMP (earliest Jurassic) and a later episode associated with the emplacement of all of the SDR's and possibly some of the igneous activity in the southern segment of the rift system. This scenario also implies that rifting ceased and inversion began in the southern segment of the rift system before the onset of seafloor spreading. Presumably, localized extensional deformation continued at the eventual site of continental breakup. In this scenario, the cause of the NW-SE compression responsible for the NW-trending dikes of CAMP age is unexplained. In scenario 2, the initiation of seafloor spreading was diachronous, beginning in the southern segment of the rift system during latest Triassic to earliest Jurassic time and beginning in the northern segment during late Early Jurassic to early Middle Jurassic time. With this scenario, the emplacement of the SDR's on the margin of eastern North America was diachronous (latest Triassic/earliest Jurassic in the south and late Early Jurassic to early Middle Jurassic in the north). As in scenario 1, two distinct episodes of magmatism affected eastern North America: CAMP (including the southern SDR's) and a later episode associated with the emplacement of the northern SDR's (late Early Jurassic to early Middle Jurassic). This scenario also implies that the cessation of rifting and the onset of inversion occurred during the transition from rifting to drifting on both the northern and southern segments of the rift system. Coring and dating the postrift basalts and the SDR's is critical to deciding which scenario is most viable. This is a key scientific goal of the Pole-to-Pole Pangea Coring Project [McHone et al., 2002; Schlische et al., 2002b].

We believe that several lines of evidence support scenario 2. 1. Numerical simulations by Bott [1992] suggest 
that a change in the stress state is likely to occur during the rift-drift transition. 2. On many volcanic passive margins, the timing of the rift-drift transition and LIP magmatism are synchronous (e.g., the passive margins of the North Atlantic Ocean) [e.g., White, 1992]. 3. By analyzing subsidence curves, Dunbar and Sawyer [1989] proposed that spreading first began between the Blake Spur and Delaware Bay fracture zones and then subsequently initiated between the Delaware Bay and Newfoundland fracture zones (Figure 1). These and other fracture zones may have accommodated some of the differences in strain between the area that was undergoing seafloor spreading and the area to the north that was still undergoing continental extension. 4. The inferred diachronous initiation of spreading for the central North Atlantic Ocean is part of regional trend that reflects the progressive breakup of Pangea. Seafloor spreading between the Grand Banks and southwestern Europe began during the Early Cretaceous [e.g., Srivastava and Tapscott, 1986]; seafloor spreading between Labrador and western Greenland began during the early Tertiary (anomaly 27N) [e.g., Chalmers et al., 1993]; seafloor spreading between eastern Greenland and northwestern Europe began slightly later during the early Tertiary (anomaly 24R) [e.g., Talwani and Eldholm, 1977; Hinz et al., 1993].

\subsection{Relationship to Middle Jurassic Hydrothermal Event}

Inversion in the southern rift segment is temporally associated with CAMP and possibly with the emplacement of SDR's at the continent-ocean boundary. Inversion in the northern basins is broadly contemporaneous with an inferred hydrothermal event $(\sim 175-$ $178 \mathrm{Ma}$ ) that reset many isotopic clocks [Sutter, 1988], that remagnetized many rocks [Witte and Kent, 1991; Witte et al., 1991], and that may be temporally associated with the emplacement of SDR's during the initiation of seafloor spreading along the northern segment of the central North Atlantic margin. -Sutter [1988] hypothesized that the hydrothermal fluids migrated in response to regional tilting and/or uplift. Schlische and Olsen [1990] attributed this fluid flow to a period of accelerated normal faulting immediately prior to breakup. However, faulting, tilting, and uplift during inversion is equally plausible. For example, Schlische [2002] described a NE-striking reverse fault from the Newark basin that exhibits evidence of extensive fluid flow. Paleomagnetic data from the Jacksonwald and Sassamansville synclines of the Newark basin show that the magnetization component related to the hydrothermal event was acquired during folding [Witte and Kent, 1991; Kodama et al., 1994]. Both synclines probably initiated as synrift fault-displacement folds [Schlische, 1992, 1995], but the presence of very steep dips and axial planar cleavage suggest that the folds were amplified during inversion. The paleomagnetic data suggest that the inversion occurred penecontemporaneously with the hydrothermal event. Interestingly, Sibson [1995] argued that high fluid pressures are required to reverse-reactivate normal faults that are not optimally oriented (i.e., those dipping steeper than $50^{\circ}$ ) and that fluid pressures increase during inversion as open subvertical fractures close during regional subhorizontal compression. Thus, inversion, fluid flow, and hydrothermal activity are all related processes.

\subsection{Uncertainties in Inversion-Related Shortening Di- rection and Magnitude}

The shortening direction for the southern rift segment is relatively well constrained because it is likely subparallel to $S_{\text {Hmax }}$ inferred from the CAMP dikes, i.e., NW-SE for the NW-trending set and N-S for the N-trending set (Figure 6). However, it is not known why the $S_{H \max }$ and the shortening direction rotated from NW-SE to N-S between the emplacement of the two sets of dikes.

The shortening direction for the northern rift segment is not as well constrained because it post-dates the CAMP dikes. Withjack et al. [1995] inferred that the shortening direction was NW-SE for the Fundy basin, based principally on the mean orientation of inversion-related folds and reverse- and oblique-slip faults associated with inversion structures (Figure 7b, c). DeBoer [1992] used smallscale faults to infer a NE-SW shortening direction for the Fundy basin. DeBoer and Clifton [1988] also used smallscale faults to infer a NE-SW shortening direction for the Hartford basin. In the Newark basin, Lomando and Engelder [1984] inferred a N-S shortening direction based on calcite twins, whereas Lucas et al. [1988] inferred a NNE-SSW shortening direction based on the geometry of the Jacksonwald syncline and its axial planar cleavage.

Part of the uncertainty is related to the fact that inversion structures are inexact recorders of the shortening direction. By definition, inversion structures are twophase structures that must have undergone an earlier extensional phase of deformation. Thus, the attitude of an inversion structure is, at least in part, controlled by the original extensional geometry. In addition, experimental modeling of reactivated structures shows that both extensional and contractional forced folds form subparallel to the trend of a preexisting fault, even where the shortening direction is oblique to the trend of the fault [Schlische et al., 1999a, b, 2002a; Tindall et al., 1999a, b]. Postrift contractional structures that did not have an earlier extensional phase are more likely to reflect the true shortening 
direction. Regional analyses of inversion structures may be useful in constraining the shortening direction. As shown in Figure 12, different shortening directions result in different senses of displacement on the differently oriented boundary faults of various eastern North American rift basins.

Experimental clay models [Eisenstadt and Withjack, 1995] indicate that the basin-scale inversion structures may be difficult to detect. Obvious basinscale inversion folds only develop in the models when the amount of shortening is equal to or greater than the amount of extension (Figure 4c). However, if erosion removes the upper part of the model, the majority of the inversion-related regional fold disappears, leaving a classical half-graben basin with somewhat steeper dips than normal (which may be misinterpreted to indicate higher amounts of regional extension). The foregoing discussion suggests that inversion in eastern North America may be even more widespread than currently appreciated.

\subsection{Applications to Other Passive Margins}

In addition to the central North Atlantic passive margin, inversion in a passive-margin setting has occurred along the Norwegian margin of the North Atlantic Ocean [e.g., Doré and Lundin, 1996; Vågnes et al., 1998], the southeastern Australian margin [e.g., Hill et al., 1995], and the Northwest Shelf of Australia [e.g., Malcolm et al., 1991; Withjack and Eisenstadt, 1999] (Figure 4b). Like the central North Atlantic margin, the Norwegian margin is a volcanic passive margin [e.g., Hinz, 1981; Hinz et al., 1993], and parts of the Northwest Shelf of Australia are volcanic [Hopper et al., 1992]. On the Norwegian margin, inversion began soon after the initiation of seafloor spreading [Vågnes et al., 1998] and continued into Miocene time. Inversion may have occurred on the Australia margin soon after the initiation of seafloor spreading [Withjack and Eisenstadt, 1999]. Significant inversion occurred during late Miocene time [Malcolm et al., 1991; Withjack and Eisenstadt, 1999].

A key feature related to inversion during the riftdrift transition is the presence of dikes trending at a high angle to the continental margin. A number of other rifted margins have dikes oriented at a high angle to the rifted margin [e.g., White, 1992]. These include the east Greenland and United Kingdom margins of the northern North Atlantic (breakup age: $55 \mathrm{Ma}$ ); the southwest India margin (breakup age: 65 $\mathrm{Ma}$ ); and the southeastern margin of South America of the southern South Atlantic (breakup age: $130 \mathrm{Ma}$ ) (Figures 5b, c, d). Interestingly, in the last example, both margin-perpendicular and margin-parallel dike sets are present, and, like the central North Atlantic region, is associated with south-to-north diachronous initiation of seafloor spreading [White, 1992]. Although all three examples discussed here are associated with mantle plumes and White [1992] related the dikes to lateral transport away from the plume head, we speculate that the dike orientations may be more indicative of a change in stress state (from rifting to inversion) that is broadly contemporaneous with the rift-drift transition on volcanic passive margins.

\subsection{Causes of Inversion on Passive Margins}

The causes of shortening on passive margins include plate collision or subduction, ridge-push forces, continental resistance to plate motion, and active asthenospheric upwelling [e.g., Dewey, 1988; Bott, 1992; Boldreel and Anderson, 1993; Withjack et al., 1998; Vågnes et al., 1998]. The last two are likely to be most intense during the rift-drift transition and the earliest stages of drifting and to act in concert to produce shortening on the passive margin. Holbrook and Kelemen [1993] and Kelemen and Holbrook [1995] argued that active asthenospheric upwelling (in which the upwelling rate is greater than the lithospheric extension rate) is necessary to produce the volume and seismic velocities of the SDR's along the central North Atlantic margin. The active asthenospheric upwelling is a type of convection driven in part by the change in lithospheric thickness across the rifted zone [e.g., Mutter et al., 1988] and possibly aided by the presence of a thermal anomaly associated with the thermal-blanketing effect of the Pangean supercontinent [e.g., Anderson, 1982]. The active asthenospheric upwelling would occur along a laterally extensive, linear zone rather than the domal or radial zone associated with a mantle plume. (Additional evidence against a mantle-plume origin for the eastern North American Jurassic magmatism is discussed in Kelemen and Holbrook [1993], McHone [2000], and Puffer [2001].)

In the geodynamic model of Withjack et al. [1998], the lithospheric mantle and the asthenosphere are initially partially decoupled (Figure 13). This means that the displacement rates of the lithosphere and the asthenosphere are slightly different. Prior to plate rupture, this leads to widespread intraplate extension (Figure 13a). Following plate rupture, the mantle lithosphere is likely to become coupled to the asthenosphere near the spreading center, whereas they remain uncoupled farther away from the spreading center. Because the portion of the plate adjacent to the spreading center is moving at a faster rate than the portion of the plate farther from the spreading center, compensating crustal shortening occurs in this region (Figure 13b). In this model, the shortening is expected to 
decrease in magnitude through time because (1) continental resistance to plate motion decreases as the lithosphere and asthenosphere become increasingly coupled, and (2) active asthenospheric upwelling gives rise to passive upwelling associated with normal seafloor-spreading processes (Figure 13c). Compressional stresses will not disappear entirely, as ridge-push forces will always be present. These ridge-push forces may be responsible, at least in part, for the reverse faults that have offset coastal plain deposits [e.g., Prowell, 1988] and may contribute to the present-day state of stress [e.g., Zoback and Zoback, 1989]. However, the present-day $\mathrm{S}_{\mathrm{H} \max }$ is oriented NE-SW, which is not parallel to the presentday spreading direction (WNW-ESE) and the presumable direction of ridge push.

The diachronous rift-drift transition (scenario 2) has additional (albeit speculative) implications for this geodynamic model involving active asthenospheric upwelling. Along the southern segment of the margin, both CAMP and the SDR's are related to the active asthenospheric upwelling that culiminated during the rift-drift transition. CAMP magmatism along the northern segment of the margin may reflect "leakage" or lateral transport of the mostly southern magmas into the region that was still undergoing continental extension. In this case, the magmatism ceased abruptly (while continental extension continued) because the formation of the SDR's and the transition to normal seafloor spreading along the southern segment of the margin largely dissipated the original thermal anomaly in the source region for much of the magma. This thermal anomaly would not have been dissipated (or not dissipated sufficiently) along the northern segment of the margin, thus leading to the formation of SDR's during the active asthenospheric upwelling that culminated during the younger rift-drift transition. This geodynamic model of active asthenospheric upwelling coupled with a diachronous rift-drift transition therefore predicts that a given rifted margin may experience multiple magmatic pulses (some of which are synrift, some of which are postrift) and that the SDR's are diachronous along the margin, as observed on many volcanic margins [Menzies et al., 2000].

\section{SUMMARY AND CONCLUSIONS}

1. CAMP igneous activity is an excellent temporal benchmark for assessing the timing of tectonic activity because it is well dated and of short duration.

2. Many of the rift basins in the eastern North American rift system have undergone basin inversion.
3. Along the southern segment of the central North Atlantic margin, rifting ended prior to CAMP igneous activity, while rifting continued during and after CAMP along the northern segment.

4. Along the southern segment of the central North Atlantic margin, basin inversion began prior to CAMP igneous activity. Along the northern segment, inversion began after CAMP igneous activity (i.e, after synrift deposition in Early Jurassic time) and ended before or during the Early Cretaceous.

5. The end of rifting and the initiation of inversion were diachronous along the central North Atlantic margin.

6. It is likely that the initiation of seafloor spreading was diachronous along the central North Atlantic margin. If so, then the rift-drift transition is associated with a change in the strain state from NW-SE extension to NWSE to N-S shortening along the southern segment of the central North Atlantic margin. Also, SDR's, emplaced during the rift-drift transition, have different ages along the length of the margin.

7. Widespread magmatism and inversion in eastern North America are related to active asthenospheric upwelling that peaked during the rift-drift transition.

Acknowledgments We thank the editors of this volume for encouraging this contribution; Mark Baum, Jennifer Elder Brady, Dennis Kent, Peter LeTourneau, Maryann Malinconico, and Peter Rona for useful discussions; and Richard Benson, Georgia Pe-Piper, and Robert Sheridan for their helpful reviews.

\section{REFERENCES}

Ackermann, R. V., R. W. Schlische, L. C. Patiño, and L. A. Johnson, A Lagerstätte of rift-related tectonic structures from the Solite Quarry, Dan River/Danville rift basin, in Aspects of Triassic-Jurassic Rift Basin Geoscience, edited by P. M. LeTourneau, and P. E. Olsen, Columbia University Press, New York, in press, 2002.

Anderson, D. L., Hotspots, polar wander, Mesozic convection, and the geoid, Nature, 297, 391-393, 1982.

Austin, J. A., and seven others, Crustal structure of the Southeast Georgia embayment-Carolina trough: preliminary results of a composite seismic image of a continental suture(?) and a volcanic passive margin, Geology, 18, 1023-1027, 1990.

Behrendt, J. C., R. M. Hamilton, H. D. Ackermann, and V. J. Henry, Cenozoic faulting in the vicinity of the Charleston, South Carolina, 1886 earthquake, Geology, 9, 117-122, 1981.

Benson, R. N., and R. G. Doyle, Early Mesozoic rift basins and the development of the United States middle Atlantic continental margin, in Triassic-Jurassic Rifting, Continental Breakup and the Origin of the Atlantic Ocean and Passive Margins, edited by W. Manspeizer, Elsevier, New York, pp. 99-127, 1988.

Boldreel, L. O., and M. S. Andersen, Late Paleocene to Miocene compression in the Faero-Rockall area, in Petroleum Geology 
of Northwest Europe, edited by J. R. Parker, Geological Society, London, pp. 1025-1034, 1993.

Bott, M. H. P., The stress regime associated with continental break-up, in Magmatism and the Causes of Continental Break-up, edited by B. C. Storey, et al., Geol. Soc. Spec. Publ., 68, 125-136, 1992.

Brun, J.-P., and T. Nalpas, Graben inversion in nature and experiments, Tectonics, 15, 677-687, 1996.

Buchanan, P. G., and K. R. McClay, Sandbox experiments of inverted listric and planar fault systems, Tectonophysics, 188, 97-115, 1991.

Chalmers, J. A., C. R. Pulvertaft, F. G. Christiansen, H. C. Laresen, K. H. Laursen, and T. G. Ottesen, The southern West Greenland continental margin: Rifting history, basin development, and petroleum potential, in Petroleum Geology of Northwest Europe, edited by J. R. Parker, Geological Society, London, pp. 915-931, 1993.

Costain, J. K., and C. Coruh, Tectonic setting of Triassic half-grabens in the Appalachians: Seismic data acquisition, processing, and results, in Extensional Tectonics and Stratigraphy of the North Atlantic Margins, edited by A. J. Tankard andH. R. Balkwill, AAPG Mem., 46, 155-174, 1989.

deBoer, J. Z., Stress configurations during and following emplacement of ENA basalts in the northern Appalachians, in Eastern North American Mesozoic Magmatism, edited by J. H. Puffer and P. C. Ragland, Geol. Soc. Am. Spec. Paper, 268, 361-378, 1992.

deBoer, J. Z., and A. E. Clifton, Mesozoic tectogenesis: Development and deformation of 'Newark' rift zones in the Appalachians (with special emphasis on the Hartford basin, Connecticut), in Triassic-Jurassic Rifting, Continental Breakup and the Origin of the Atlantic Ocean and Passive Margins, edited by W. Manspeizer, Elsevier, New York, pp. 275-306, 1988.

de Graciansky, P. C., G. Dardeau, M. Lemoine, and P. Tricart, The inverted margin of the French Alps and foreland basin inversion, in Inversion Tectonics, edited by M. A. Cooper and G. D. William, Geol. Soc. Spec. Publ., 44, 87-104, 1989.

Dewey, J. F., Lithospheric stress, deformation, and tectonic cycles: The disruption of Pangaea and the closure of the Tethys, in Gondwana and Tethys, edited by M. G. Audley-Charles and A. Hallam, Geol. Soc. Spec. Publ., 37, 23-40, 1988.

Dietz, R. S., and J. C. Holden, Reconstruction of Pangaea: breakup and dispersion of continents, Permian to present J. Geophy. Res., 75, 4939-4956, 1970.

Dore, A. G., and E. R. Lundin, Cenozoic compressional structures on the NE Atlantic margin: Nature, origin, and potential significance for hydrocarbon exploration, Petrol. Geoscience, 2, 299-311, 1996.

Dunbar, J. A., and D. S. Sawyer, Patterns of continental extension along the conjugate margins of the central and North Atlantic Oceans and Labrador Sea, Tectonics, 8, 1059-1077, 1989.

Dunn, A. M., P. H. Reynolds, D. B. Clarke, J. M. Ugidos, A comparison of the age and composition of the Shel- burne dyke, Nova Scotia, and the Messejana dyke, Spain, Can. J. Earth Sci., 35, 1110-1115, 1998.

Dunning, G. R., and J. D. Hodych, U-Pb zircon and baddeleyite age for the Palisade and Gettysburg sills of northeast United States: Implications for the age of the Triassic-Jurassic boundary, Geology, 18, 795-798, 1990.

Eisenstadt, G., and M. O. Withjack, Estimating inversion: results from clay models, in Basin Inversion, edited by J. G. Buchanan and P. G. Buchanan, Geol. Soc. Spec. Publ., 88, 119136, 1995.

Fedosh, M. S., and J. P. Smoot, A cored stratigraphic section through the northern Newark basin, New Jersey, in Studies of the Early Mesozoic Basins of the Eastern United States, edited by A. J. Froelich and G. R. Robinson, Jr., U.S. Geol. Surv. Bull., 1776, 19-24, 1988.

Fowell, S. J., B. Cornet, and P. E. Olsen, Geologically rapid Late Triassic extinctions: Palynological evidence from the Newark Supergroup, Geol. Soc. Am. Spec. Paper, 288, $197-$ 206, 1994

Froelich, A. J., and P. E. Olsen, Newark Supergroup, a revision of the Newark Group in eastern North America, U.S. Geol. Surv. Bull., 1537A, A55-A58, 1984.

Ginger, D. C., W. O. Ardjakusumah, R. J. Hedley, and J. Pothecary, Inversion history of the West Natuna basin: Examples from the Cumi-Cumi PSC, in Proceedings Indonesian Petrol. Assoc., 22 ${ }^{\text {nd }}$ Ann. Convention, IPA93-1.1-171, pp. 635-657, 1993.

Hames, W. E., P. R. Renne, and C. Ruppel, New evidence for geologically instantaneous emplacement of earliest Jurassic Central Atlantic magmatic province basalts on the North American margin, Geology, 28, 859-862, 2000.

Hamilton, R. M., J. C. Behrendt, and H. D. Ackermann, Land multichannel seismic-reflection evidence for tectonic features near Charleston, South Carolina, in Studies Related to the Charleston, South Carolina, Earthquake of 1886 - Tectonics and Seismicity, edited by G. S. Gohn, U.S. Geol. Surv. Prof. Paper, 1313, I1-I18, 1983.

Hill, K. C., K. A. Hill, G. T. Cooper, A. J. O'Sullivan, P. B. O'Sullivan, and M. J. Richardson, Inversion around the Bass basin, SE Australia, in Basin Inversion, edited by J. G. Buchanan and P. G. Buchanan, Geol. Soc. Spec. Publ., 88, 525548, 1995 .

Hill, R. I., Starting plumes and continental breakup, Earth Planet. Sci. Lett., 87, 398-416, 1991.

Hinz, K., A hypothesis on terrestrial catastrophes; wedges of very thick, oceanward-dipping layers beneath passive continental margins, Geol. Jahrbuch, E22, 3-38, 1981.

Hinz, K., O. Eldholm, M. Block, and J. Skogseid, Evolution of North Atlantic volcanic continental margins, in Petroleum Geology of Northwest Europe, edited by J. R. Parker, Geological Society, London, pp. 901-913, 1993.

Hodych, J. P., and G. R. Dunning, Did the Manicouagan impact trigger end-of-Triassic mass extinction?, Geology, 20, 51-54, 1992.

Holbrook, W. S., and P. B. Kelemen, Large igneous province on the US Atlantic margin and implications for magmatism during continental breakup, Nature, 364, 433-436, 1993. 
Hopper, J. R., J. C. Mutter, R. L. Larson, C. Z. Mutter, and Northwest Australia Study Group, Magmatism and rift margin evolution: Evidence from northwest Australia, Geology, 20, 853-857,1992.

Hozik, M. J., Paleomagnetism of igneous rocks in the Culpeper, Newark, and Hartford/Deerfield basins, in Eastern North American Mesozoic Magmatism, edited by J. H. Puffer and P. C. Ragland, Geol. Soc. Am. Spec. Paper, 268, 279-308, 1992.

Keen, C. E., and D. P. Potter, The transition from a volcanic to a nonvolcanic rifted margin off eastern Canada, Tectonics, 14, 359-371, 1995.

Kelemen, P. B., and W. S. Holbrook, Origin of thick, highvelocity igneous crust along the U.S. east coast margin, J. Geophys. Res., 100, 10,077-10,094, 1995.

Keller, J. V. A., and K. R. McClay, 3D sandbox models of positive inversion, in Basin Inversion, edited by J. G. Buchanan and P. G. Buchanan, Geol. Soc. Spec. Publ., 88, 137-146, 1995.

Kent, D. V., P. E. Olsen, and W. K. Witte, Late Triassicearliest Jurassic geomagnetic polarity sequence and paleolatitudes from drill cores in the Newark rift basin, eastern North America, J. Geophys. Res., 100, 14,96514,998, 1995.

King, P. B., Systematic pattern of Triassic dikes in the Appalachian region, second report, U.S. Geol. Surv. Prof. Paper, 750D, D84-D88, 1971.

King, S. D., and D. L. Anderson, Edge-driven convection, Earth Planet. Sci. Lett., 160, 289-296, 1998.

Klitgord, K. D., and H. Schouten, Plate kinematics of the central Atlantic, in The Geology of North America, v. M, The Western North Atlantic Region, edited by P. R. Vogt and B. E. Tucholke, Geological Society of America, Boulder, pp. 351-378, 1986.

Klitgord, K. D., D. R. Hutchinson, and H. Schouten, U.S. Atlantic continental margin; structural and tectonic framework, in The Geology of North America, v. I-2, The Atlantic Continental Margin, U.S., edited by R. E. Sheridan and J. A. Grow, Geological Society of America, Boulder, pp. 19-56, 1988.

Kodama, K. P., C. Hedlund, J. Gosse, and J. Strasser, Rotated paleomagnetic poles from the Sassamansville syncline, Newark basin, southeastern Pennsylvania, J. Geophys. Res., 99, 4643-4653, 1994.

Lanphere, M. A., ${ }^{40} \mathrm{Ar} /{ }^{39} \mathrm{Ar}$ ages of basalt from Clubhouse Crossroads test hole \#2, near Charleston, South Carolina, in Studies Related to the Charleston, South Carolina, Earthquake of 1886 - Tectonics and Seismicity, edited by G. S. Gohn, U.S. Geol. Surv. Prof. Paper, 1313, B1B8, 1983.

LeTourneau, P. M., Depositional history and tectonic evolution of Late Triassic age rifts of the U.S. Central Atlantic margin: Results of an integrated stratigraphic, structural, and paleomagnetic analysis of the Taylorsville and Richmond basins, Ph.D. thesis, Columbia University in the City of New York, 1999.

LeTourneau, P. M., and N. G. McDonald, Facies analysis of Early Jurassic lacustrine sequences, Hartford basin,
Connecticut and Massachusetts, Geol. Soc. Am. Abstr. Programs, 20, 32, 1988.

Letouzey, J., Fault reactivation, inversion, and fold-thrust belt, in Petroleum and Tectonics in Mobile Belts, edited by J. Letouzey, IFP Editions Technip, Paris, pp. 101-128, 1990.

Lindholm, R. C., Triassic-Jurassic faulting in eastern North America--a model based on pre-Triassic structures, Geology, 6, 365-368, 1978.

Lomando, A. J., and T. Engelder, Strain within the rocks of the Newark basin, New York, Geol. Soc. Am. Abstr. Programs, 12:2, 70-71, 1980.

Lucas, M., J. Hull, and W. Manspeizer, A foreland-type fold and related structures of the Newark rift basin, in TriassicJurassic Rifting, Continental Breakup and the Origin of the Atlantic Ocean and Passive Margins, edited by W. Manspeizer, Elsevier, New York, pp. 307-332, 1988.

MacLean, B. C., and J. A. Wade, Petroleum geology of the continental margin south of the islands of St. Pierre and Miquelon, offshore eastern Canada, Bull. Can. Petrol. Geol., 40, 222-253, 1992.

Malcolm, R. J., M. C. Pott, E. Delfos, A new tectonostratigraphic synthesis of the north west Cape area, APEA Journal, 31, 154-176, 1991.

Malinconico, M. L., Thermal history of the Early Mesozoic Newark (NJ/PA) and Taylorsville (VA) basins using borehole vitrinite reflectance: conductive and advective effects, Geol. Soc. Am. Abstr. Programs, 31:2, A-31, 1999.

Malinconico, M. L., Estimates of eroded strata using borehole vitrinite reflectance data, Triassic Taylorsville rift basin, Virginia: Implications for duration of syn-rift sedimentation and evidence of structural inversion, in Aspects of TriassicJurassic Rift Basin Geoscience, edited by P. M. LeTourneau and P. E. Olsen, Columbia University Press, New York, in press, 2002.

Manspeizer, W., Rift tectonics inferred from volcanic and clastic structures, in Field Studies of New Jersey Geology and Guide to Field Trips, edited by W. Manspeizer, 52nd Annual Meeting of the New York State Geological Association, Rutgers University, Newark, N.J., pp. 314-350, 1980.

Manspeizer, W., Triassic-Jurassic rifting and opening of the Atlantic: An overview, in Triassic-Jurassic Rifting, Continental Breakup and the Origin of the Atlantic Ocean and Passive Margins, edited by W. Manspeizer, Elsevier, New York, pp. 41-79, 1988.

Marzolli, A., P. R. Renne, E. M. Piccirillo, M. Ernesto, G. Bellieni, and A. De Min, Extensive 200-million-year-old continental flood basalts of the Central Atlantic Magmatic Province, Science, 284, 616-618, 1999.

May, P. R., Pattern of Triassic-Jurassic diabase dikes around the North Atlantic in the context of the predrift configuration of the continents, Geol. Soc. Am. Bull., 82, 1285-1292, 1971.

McBride, J. H., K. D. Nelson, and L. D. Brown, Evidence and implications of an extensive early Mesozoic rift basin and basalt/diabase sequence beneath the southeast Coastal Plain, Geol. Soc. Am. Bull., 101, 512-520, 1989.

McHone, J. G., Tectonic and paleostress patterns of Mesozoic intrusions in eastern North America, in Triassic-Jurassic Rifting, Continental Breakup and the Origin of the Atlantic 
Ocean and Passive Margins, edited by W. Manspeizer, Elsevier, New York, pp. 607-620, 1988.

McHone, J. G., Broad-terrane Jurassic flood basalts across northeastern North America, Geology, 24, 319-322, 1996.

McHone, J. G., Non-plume magmatism and rifting during the opening of the central Atlantic Ocean, Tectonophysics, 316, 287-296, 2000.

McHone, J. G., M. Talwani, W. Hames, A. Marzoli, P. Ragland, B. Turrin, M. Coffin, S. Barr, C. White, and D. Morris, Large igneous provinces, seaward dipping reflectors, and Central Atlantic Magmatic Province, in Climatic, Biotic, and Tectonic Pole-to-Pole Coring Transect of Triassic-Jurassic Pangea, edited by P. E. Olsen and D. V. Kent, International Continental Drilling Program, in press, 2002.

Menzies, M. A., C. Ebinger, and S. Klemperer, Penrose Conference report: Volcanic rifted margins, GSA Today, August 2000, 8-11, 2000.

Mitra, S., and Q. T. Islam, Experimental (clay) models of inversion structures, Tectonophysics, 230, 211-222, 1994.

Mutter, J. C., W. R. Buck, and C. M. Zehnder, Convective partial melting I: A model for formation of thick igneous sequences during initiation of spreading, J. Geophys. Res., 93, 1031-1048, 1988.

Oh, J., J. A. Austin, Jr., J. D. Phillips, M. F. Coffin, and P. L. Stoffa, Seaward-dipping reflectors offshore the southeastern United States: Seismic evidence for extensive volcanism accompanying sequential formation of the Carolina trough and Blake Plateau basin, Geology, 23, 9 12, 1995.

Olsen, P. E., Stratigraphic record of the early Mesozoic breakup of Pangea in the Laurasia-Gondwana rift system, Ann. Rev. Earth Planet. Sci., 25, 337-401, 1997.

Olsen, P. E., Giant lava flows, mass extinctions, and mantle plumes, Science, 284, 604-605, 1999.

Olsen, P. E., and R.W. Schlische, Transtensional arm of the early Mesozoic Fundy rift basin: Penecontemporaneous faulting and sedimentation, Geology, 18, 695-698, 1990.

Olsen, P. E., R. W. Schlische, and P. J. W. Gore, Tectonic, Depositional, and Paleoecological History of Early Mesozoic Rift Basins of Eastern North America, International Geological Congress Field Trip T-351, AGU, Washington, 174 pp., 1989.

Olsen, P. E., D. V. Kent, B. Cornet, W. K. Witte, and R. W. Schlische, High-resolution stratigraphy of the Newark rift basin (early Mesozoic, eastern North America), Geol. Soc. Am. Bull., 108, 40-77, 1996a.

Olsen, P. E., R. W. Schlische, and M. S. Fedosh, 580 kyr duration of the Early Jurassic flood basalt event in eastern North America estimated using Milankovitch cyclostratigraphy, in The Continental Jurassic, edited by M. Morales, Museum of Northern Arizona Bull., 60, 1122, 1996b.

Parker, R. A., H. F. Houghton, and R. C. McDowell, Stratigraphic framework and distribution of early Mesozoic rocks of the northern Newark basin, New Jersey and
New York, in Studies of the Early Mesozoic Basins of the Eastern United States, edited by A. J. Froelich and G. R. Robinson, Jr., U.S. Geol. Surv. Bull., 1776, 31-39, 1988.

Phillips, J. D., Paleomagnetic investigations of the Clubhouse Crossroads basalt, U.S. Geol. Surv. Prof. Paper, 1313-C, 118, 1983.

Philpotts, A. R., and A. Martello, Diabase feeder dikes for the Mesozoic basalts in southern New England, Am. J. Sci., 286, 105-126, 1986.

Poag, C. W., and P. C. Valentine, Mesozoic and Cenozoic stratigraphy of the United States Atlantic continental shelf and slope, in The Geology of North America, v. I-2, The Atlantic Continental Margin, U.S., edited by R. E. Sheridan and J. A. Grow, Geological Society of America, Boulder, pp. 67-85, 1988.

Pratt, L. M., C. A. Shaw, and R. C. Burruss, Thermal histories of the Hartford and Newark Basins inferred from maturation indices of organic matter, in Studies of the Early Mesozoic Basins of the Eastern United States, edited by A. J. Froelich and G. R. Robinson, Jr., U.S. Geol. Surv. Bull., 1776, 58-62, 1988.

Prevot, M., and M. McWilliams, Paleomagnetic correlation of the Newark Supergroup volcanics, Geology, 17, 1007-1010, 1989.

Prowell, D. C., Cretaceous and Cenozoic tectonism on the Atlantic coastal margin, in The Geology of North America, v. I2, The Atlantic Continental Margin, U.S., edited by R. E. Sheridan and J. A. Grow, Geological Society of America, Boulder, pp. 557-564, 1988.

Puffer, J. H., Contrasting high field strength element contents of continental flood basalts from plume versus reactivated-arc sources, Geology, 29, 675-678, 2001.

Puffer, J. H., and A. R. Philpotts, Eastern North American quartz tholeiites: geochemistry and petrology, in TriassicJurassic Rifting, Continental Breakup and the Origin of the Atlantic Ocean and Passive Margins, edited by W. Manspeizer, Elsevier, New York, pp. 579-605, 1988.

Ragland, P. C., Mesozoic igneous rocks, in Geology of the Carolinas, edited by J. W. Horton, and V. A. Zullo, University of Tennessee Press, Knoxville, pp. 171-190, 1991.

Ragland, P. C., R. D. Hatcher, Jr., and D. Whittington, Juxtaposed Mesozoic diabase dike sets from the Carolinas: a preliminary assessment, Geology, 11, 394-399, 1983.

Ragland, P. C., L. E. Cummins, and J. D. Arthur, Compositional patterns for early Mesozoic diabases from South Carolina to central Virginia, in Eastern North American Mesozoic Magmatism, edited by J. H. Puffer and P. C. Ragland, Geol. Soc. Am. Spec. Paper, 268, 301-331, 1992.

Ratcliffe, N. M., and W. C. Burton, Fault reactivation models for the origin of the Newark basin and studies related to U.S. eastern seismicity, U.S. Geol. Surv. Circular, 946, 36-45, 1985.

Ratcliffe, N. M., W. C. Burton, R. M. D'Angelo, and J. K. Costain, Low-angle extensional faulting, reactivated mylonites, and seismic reflection geometry of the Newark Basin margin in eastern Pennsylvania, Geology, 14, 766-770, 1986.

Ratcliffe, N. M., Structural analysis of the Furlong fault and the relationship of mineralization to faulting and diabase intrusion, Newark basin, Pennsylvania, in Studies of the Early 
Mesozoic Basins of the Eastern United States, edited by A. J. Froelich and G. R. Robinson, Jr., U.S. Geol. Surv. Bull., 1776, 176-193, 1988.

Sanders, J. E., Late Triassic tectonic history of northeastern United States, Am. J. Sci., 261, 501-524, 1963.

Schlee, J. S., and K. D. Klitgord, Georges Bank basin: A regional synthesis, in The Geology of North America, v. I-2, The Atlantic Continental Margin, U.S., edited by R. E. Sheridan and J. A. Grow, Geological Society of America, Boulder, pp. 243-268, 1988.

Schlische, R. W., Structural and stratigraphic development of the Newark extensional basin, eastern North America; Implications for the growth of the basin and its bounding structures, Geol. Soc. Am. Bull., 104, 1246-1263, 1992.

Schlische, R. W., Anatomy and evolution of the TriassicJurassic continental rift system, eastern North America, Tectonics, 12, 1026-1042, 1993.

Schlische, R. W., Geometry and origin of fault-related folds in extensional settings, AAPG Bull., 79, 1661-1678, 1995.

Schlische, R. W., Progress in understanding the structural geology, basin evolution, and tectonic history of the eastern North American rift system, in Aspects of Triassic-Jurassic Rift Basin Geoscience, edited by P. M. LeTourneau and P. E. Olsen, Columbia University Press, New York, in press, 2002.

Schlische, R. W., and M. H. Anders, Stratigraphic effects and tectonic implications of the growth of normal faults and extensional basins, in Reconstructing the Structural History of Basin and Range Extension Using Sedimentology and Stratigraphy, edited by K. K. Beratan, Geol. Soc. Am. Spec. Paper, 303, 183-203, 1996.

Schlische, R. W., and P. E. Olsen, Quantitative filling model for continental extensional basins with applications to early Mesozoic rifts of eastern North America, $J$. Geol., 98, 135-155, 1990.

Schlische, R. W., M. O. Withjack, and G. Eisenstadt, Using scaled physical models to study the deformation pattern produced by basement-involved oblique extension, AAPG Ann. Meeting Abstr., 8, A-125, 1999a.

Schlische, R. W., M. O. Withjack, and G. Eisenstadt, An experimental study of the secondary fault patterns produced by oblique-slip normal faulting, Eos Trans. AGU, 80 (17), S339, 1999b.

Schlische, R. W., M. O. Withjack, and G. Eisenstadt, An experimental study of the secondary deformation produced by oblique-slip normal faulting, AAPG Bull., in press, 2002a.

Schlische, R. W., M. O. Withjack, J. A. Austin, D. E. Brown, J. Contreras, E. Gierlowski-Kordesch, L. F. Jansa., M. L. Malinconico, J. P. Smoot, and R. P. Wintsch, Basin Evolution, in Climatic, Biotic, and Tectonic Pole-to-Pole Coring Transect of Triassic-Jurassic Pangea, edited by P. E. Olsen and D. V. Kent, International Continental Drilling Program, in press, 2002b.

Sepkowski, J. J., Biodiversity: past, present and future, J. Paleont., 71, 533-539, 1997.
Shaler, N. S., and J. B. Woodworth, Geology of the Richmond basin, Virginia, U.S. Geol. Surv. Ann. Report, 19, pp. 12461263, 1899.

Sheridan, R. E., and J. A. Grow, editors, 1988, The Geology of North America, v. I-2, The Atlantic Continental Margin, U.S., Geological Society of America, Boulder, 1988.

Sheridan, R. E., D. L. Musser, L. Glover III., M. Talwani, J. I. Ewing, W. S. Holbrook, G. M. Purdy, R. Hawman, and S. Smithson, Deep seismic reflection data of EDGE U.S. midAtlantic continental-margin experiment: Implications for Appalachian sutures and Mesozoic rifting and magmatic underplating, Geology, 21, 563-567, 1993.

Sibson, R. H., Selective fault reactivation during basin inversion: potential for fluid redistribution through fault-valve action, in Basin Inversion, edited by J. G. Buchanan and P. G. Buchanan, Geol. Soc. Spec. Publ., 88, 3-19, 1995.

Smith, W. A., Paleomagnetic results from a crosscutting system of northwest and north-south trending diabase dikes in the North Carolina Piedmont, Tectonophysics, 136, 137-150, 1987.

Srivastava, S. P., and C. R. Tapscott, Plate kinematics of the North Atlantic, in The Geology of North America, v. M, The Western North Atlantic Region, edited by P. R. Vogt and B. E. Tucholke, Geological Society of America, Boulder, pp. 379404, 1986.

Steckler, M. S., G. I. Omar, G. D. Karner, and B. P. Kohn, Pattern of hydrothermal circulation with the Newark basin from fission-track analysis, Geology, 21, 735-738, 1993.

Sutter, J. F., Innovative approaches to the dating of igneous events in the early Mesozoic basins of the Eastern United States, in Studies of the Early Mesozoic Basins of the Eastern United States, edited by A. J. Froelich and G. R. Robinson, Jr., U.S. Geol. Surv. Bull., 1776, 194-200, 1988.

Swanson, M. T., Preexisting fault control for Mesozoic basin formation in eastern North America, Geology, 14, 419-422, 1986.

Talwani, M., and O. Eldholm, Evolution of the NorwegianGreenland Sea, Geol. Soc. Am. Bull., 88, 969-999, 1977.

Talwani, M., J. Ewing, R. E. Sheridan, W. S. Holbrook, and L. Glover III, The EDGE experiment and the U.S. East Coast magnetic anomaly, in Rifted Ocean-Continent Boundaries, edited by E. Banda, et al., Kluwer Academic Publishers, Dordrecht, The Netherlands, pp. 155-181, 1995.

Tankard, A. J., and H. J. Welsink, Mesozoic extension and styles of basin formation in Atlantic Canada, in Extensional Tectonics and Stratigraphy of the North Atlantic Margins, edited by A. J. Tankard and H. R. Balkwill, AAPG Mem., 46, 175-195, 1989.

Tanner, L. H., and J. F. Hubert, Basalt breccias and conglomerates in the Lower Jurassic McCoy Brook Formation, Fundy basin, Nova Scotia: Differentiation of talus and debris-flow deposits, J. Sed. Petrol., 61, 15-27, 1991.

Tindall, S. E., G. Eisenstadt, M. O. Withjack, and R. W. Schlische, Interpretation of oblique compressional structures - comparisons of field examples and physical models, AAPG Ann. Meeting Abstr., 8, A139, 1999a. 
Tindall, S. E., G. Eisenstadt, M. O. Withjack, and R. W. Schlische, Characteristic features of oblique basementcored uplifts, Geol. Soc. Am., Abstr. Programs, 31, A236, 1999b.

Tollo, R. P., and D. Gottfried, Petrochemistry of Jurassic basalt from eight cores, Newark basin, New Jersey; implications for volcanic petrogenesis of the Newark Supergroup, in Eastern North American Mesozoic Magmatism, edited by J. H. Puffer and P. C. Ragland, Geol. Soc. Am. Spec. Paper, 268, 233-259, 1992.

Tseng, H-Y., T. C. Onstott, R. C. Burruss, and D. S. Miller, Constraints on the thermal history of the Taylorsville basin, Virginia, U.S.A., from fluid-inclusion and fissiontrack analyses: implications for subsurface geomicrobiology experiments, Chem. Geol., 127, 297-311, 1996.

Turrin, B. D., ${ }^{40} \mathrm{Ar} /{ }^{39} \mathrm{Ar}$ mineral ages and potassium and argon systematics from the Palisade Sill, New York, Eos Trans. AGU, 81 (48), Fall Meet. Suppl., Abstract V72E13, 2000.

Vågnes, E., R. H. Gabrielsen, and P. Haremo, Late Cretaceous-Cenozoic intraplate contractional deformation at the Norwegian continental shelf: timing, magnitude and regional implications, Tectonophysics, 300, 29-46, 1998.

Venkatakrishnan, R., and R. Lutz, A kinematic model for the evolution of the Richmond basin, in Triassic-Jurassic Rifting, Continental Breakup and the Origin of the Atlantic Ocean and Passive Margins, edited by W. Manspeizer, Elsevier, New York, pp. 445-462, 1988.

Wade, J. A., and B. C. MacLean, The geology of the southeastern margin of Canada, in Geology of the Continental Margin of Eastern Canada, edited by M. J. Keen and G. L. Williams, Geol. Surv. Canada, Geology of Canada No. 2, 167-238, 1990.

White, R. S., Magmatism during and after continental break-up, in Magmatism and the Causes of Continental Break-up, edited by B. C. Storey, et al., Geol. Soc. Spec. Publ., 68, 1-16, 1992.

Williams, G. D., C. M. Powell, and M. A. Cooper, Geometry and kinematics of inversion tectonics, in Inversion Tectonics, edited by M. A. Cooper and G. D. William, Geol. Soc. Spec. Publ., 44, 3-15, 1989.

Wise, D. U., Dip domain method applied to the Mesozoic Connecticut Valley rift basins, Tectonics, 11, 1357-1368, 1993.

Withjack, M. O., and G. Eisenstadt, Structural history of the Northwest Shelf, Australia -- an integrated geological, geophysical and experimental approach, AAPG Ann. Meeting Abstr., 8, A151, 1999.

Withjack, M. O., P. E. Olsen, and R. W. Schlische, Tectonic evolution of the Fundy basin, Canada: Evidence for extension and shortening during passive margin formation, Tectonics, 14, 390-405, 1995.

Withjack, M. O., R. W. Schlische, and P. E. Olsen, Diachronous rifting, drifting, and inversion on the passive margin of central eastern North America: An analog for other passive margins, AAPG Bull., 82, 817-835, 1998.
Withjack, M. O., R. W. Schlische, and P. E. Olsen, Influence of rift basin structural geology on sedimentology and stratigraphy: a review, in Continental Rift Basin Sedimentology, edited by R. Renaut and G. M. Ashley, SEPM Spec. Publ., in press, 2002.

Witte, W. K., and D. V. Kent, Tectonic implications of a remagnetization event in the Newark Basin, J. Geophys. Res., 96, 19,569-19,582, 1991.

Witte, W. K., D. V. Kent, and P. E. Olsen, Magnetostratigraphy and paleomagnetic poles from Late Triassic-earliest Jurassic strata of the Newark Basin, Geol. Soc. Am. Bull., 103, 16481662, 1991.

Zoback, M. L., and M. D. Zoback, Tectonic stress field of the conterminous United States, Geol. Soc. Am. Mem., 172, 523539, 1989.

Paul E. Olsen, Department of Earth and Environmental Sciences and Lamont-Doherty Earth Observatory of Columbia University, Rt 9W, Palisades, New York 10964.

Roy W. Schlische and Martha Oliver Withjack, Department of Geological Sciences, Rutgers University, 610 Taylor Road, Piscataway, New Jersey 08854-8066. 


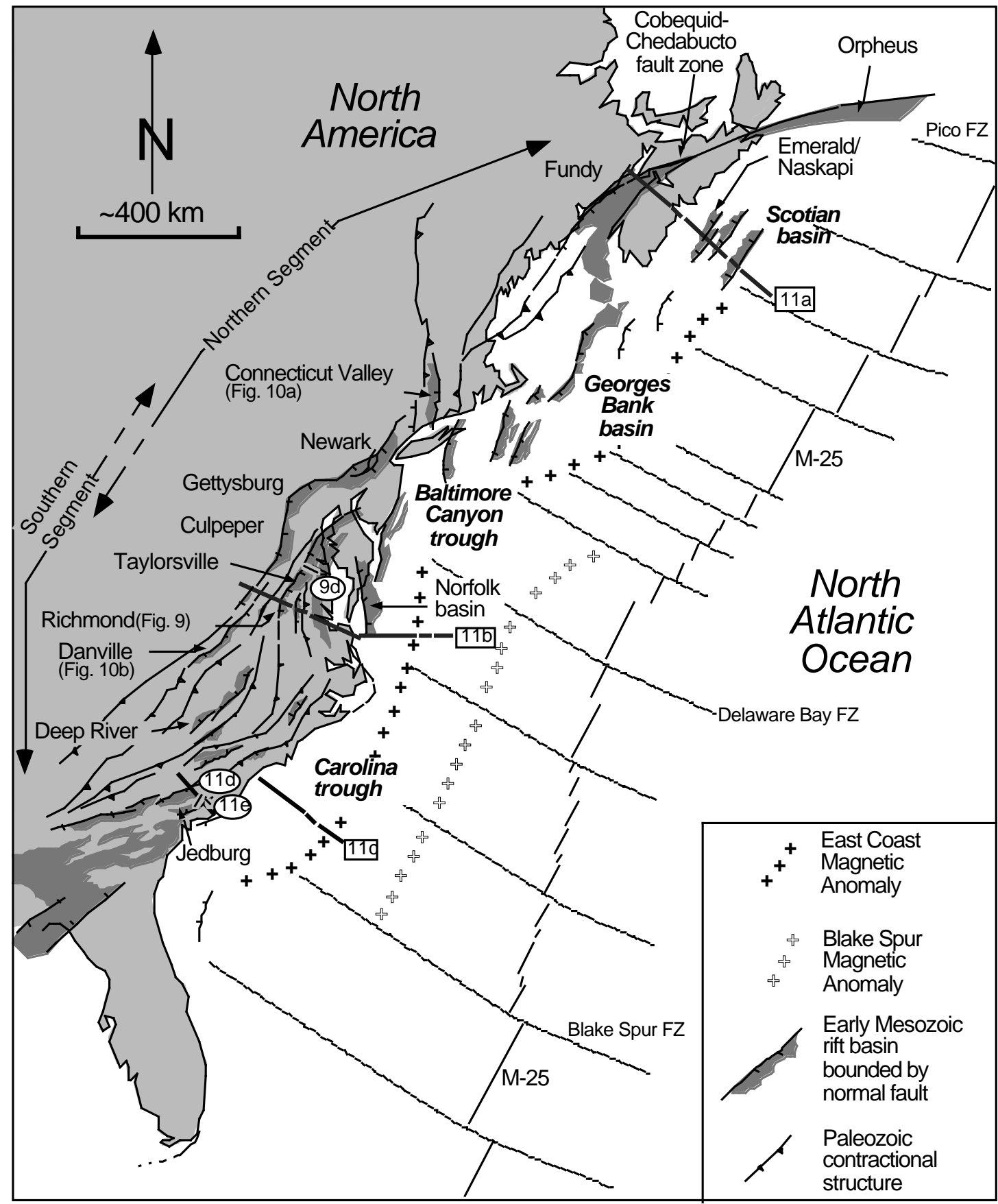

Figure 1. Major Paleozoic contractional structures, early Mesozoic rift basins of eastern North America, and key tectonic features of the eastern North Atlantic Ocean. Thick dashed lines and rectangles with notation show location of transects in Figure 11; solid lines and ellipses with notation show location of sections in Figures 9 and 11. Modified from Withjack et al. [1998]. 

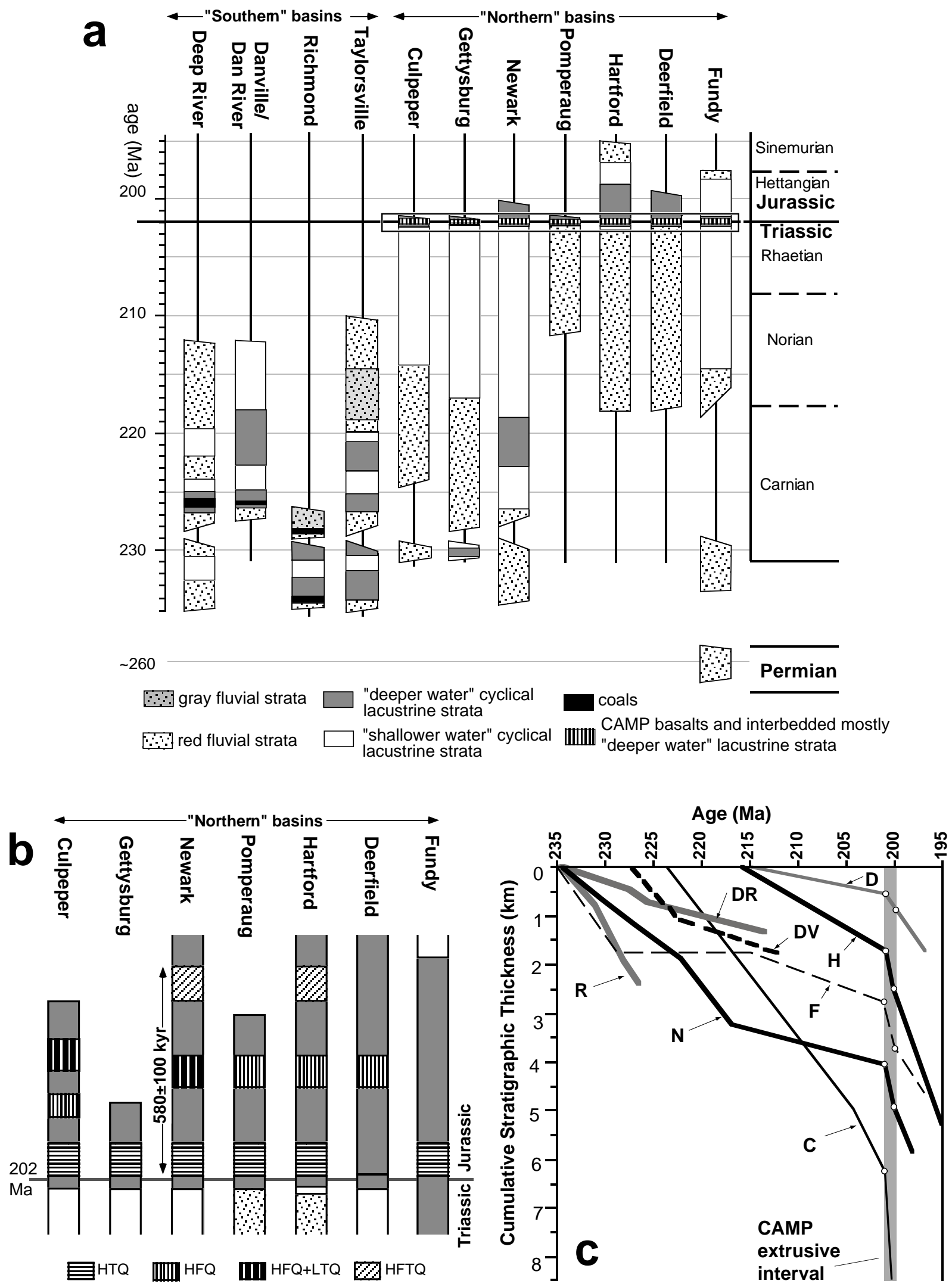

Figure 2. a) Stratigraphic architecture of eastern North American rift basins. Modified from Olsen [1997] and Schlische [2002]. b) Detail of earliest Jurassic extrusive interval (CAMP) showing correlation of basalt types by geochemistry. HTQ is high-titanium quartz-normative; HFQ is high-iron quartz-normative; LTQ is low-titanium quartz-normative; and HFTQ is high-iron and titanium quartz-normative. The duration of extrusive interval in the Newark basin, $580 \pm 100 \mathrm{kyr}$, is based on cyclostratigraphy [Olsen et al., 1996b]. Modified from Olsen [1997]. c) Cumulative stratigraphic thickness versus geologic age for various exposed rift basins in eastern North America. The Culpeper (C), Deerfield (D), Fundy (F), Hartford (H), and Newark (N) basins all show pronounced increases in stratal thickness in earliest Jurassic time (CAMP extrusive interval). Other abbreviations are DR, Deep River; DV, Danville; and R, Richmond basins. Modified from Schlische and Anders [1996]. 


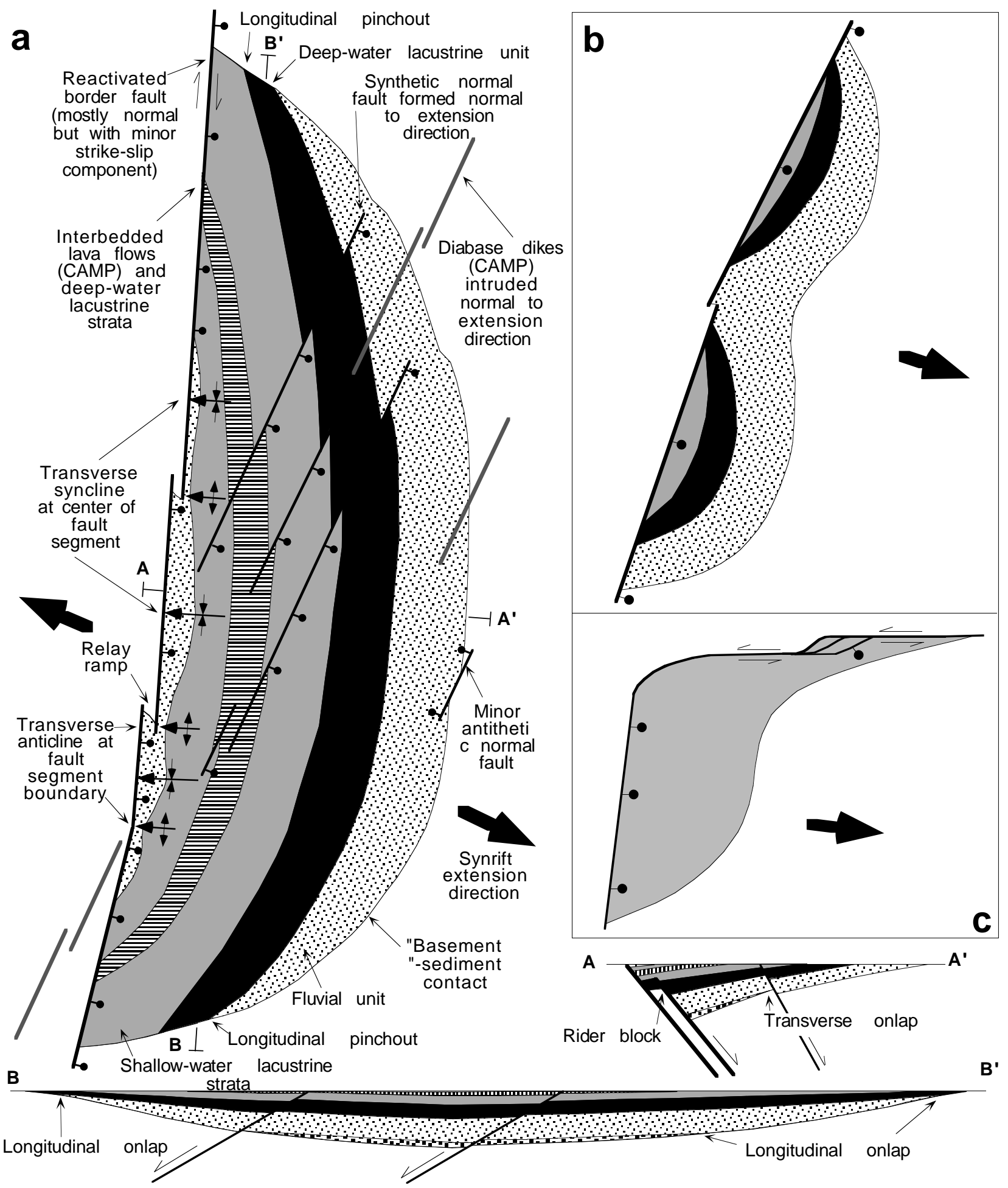

Figure 3. a) Geologic map and cross sections of an idealized, dip-slip dominated Mesozoic rift basin in eastern North America. Note that synrift units thicken toward the border fault in tranverse section and thicken toward the center of the basin in longitudinal section. b) Geologic map of idealized rift basin containing multiple subbasins related to large-scale segmentation of border-fault system. c) Geologic map of basin with both dip-slip and strikeslip-dominated margins. The basins shown in a) and b) apply strictly to the northern rift segment. The basins in the southern rift segment do not contain Jurassic lava flows or strata, and dikes are oriented at a high angle to the trend of the basin. The idealized basin geometry shown here does not include the effects of basin inversion. Modified from Schlische [1993]. 


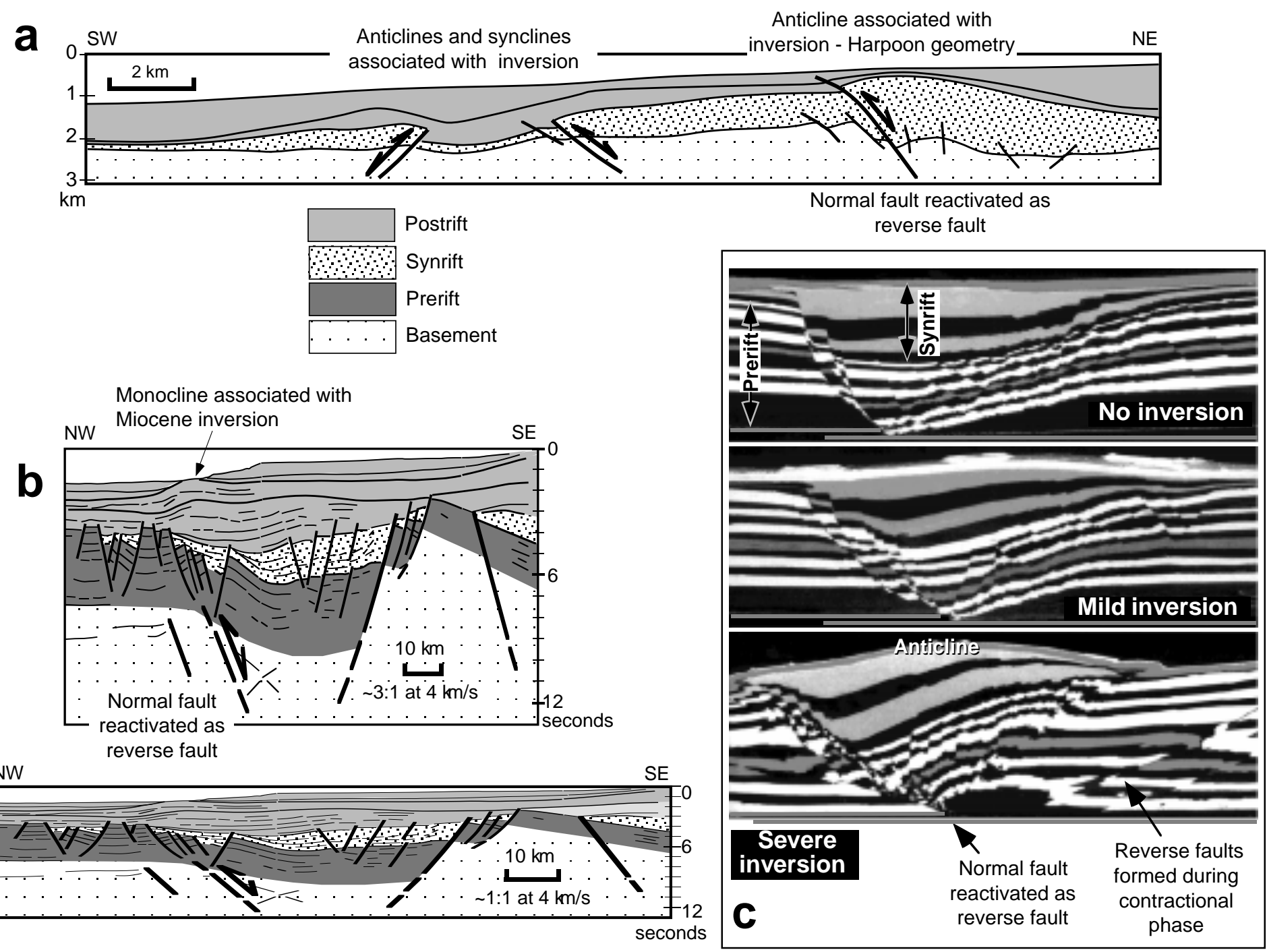

Figure 4. Examples of positive inversion structures. a) Cross section across part of Sunda arc. During inversion, normal faults became reverse faults, producing synclines and anticlines with harpoon geometries [after Letouzey, 1990]. b) Interpreted line drawings (with 3:1 and 1:1 vertical exaggeration) of AGSO Line 110-12 from Exmouth subbasin, NW Shelf Australia [after Withjack and Eisenstadt, 1999]. During Miocene inversion, deep-seated normal faults became reverse faults. In response, gentle monoclines formed in the shallow, postrift strata. c) Cross sections through three clay models showing development of inversion structures [after Eisenstadt and Withjack, 1995]. Top section shows model with extension and no shortening; middle section shows model with extension followed by minor shortening; bottom section shows model with extension followed by major shortening. 


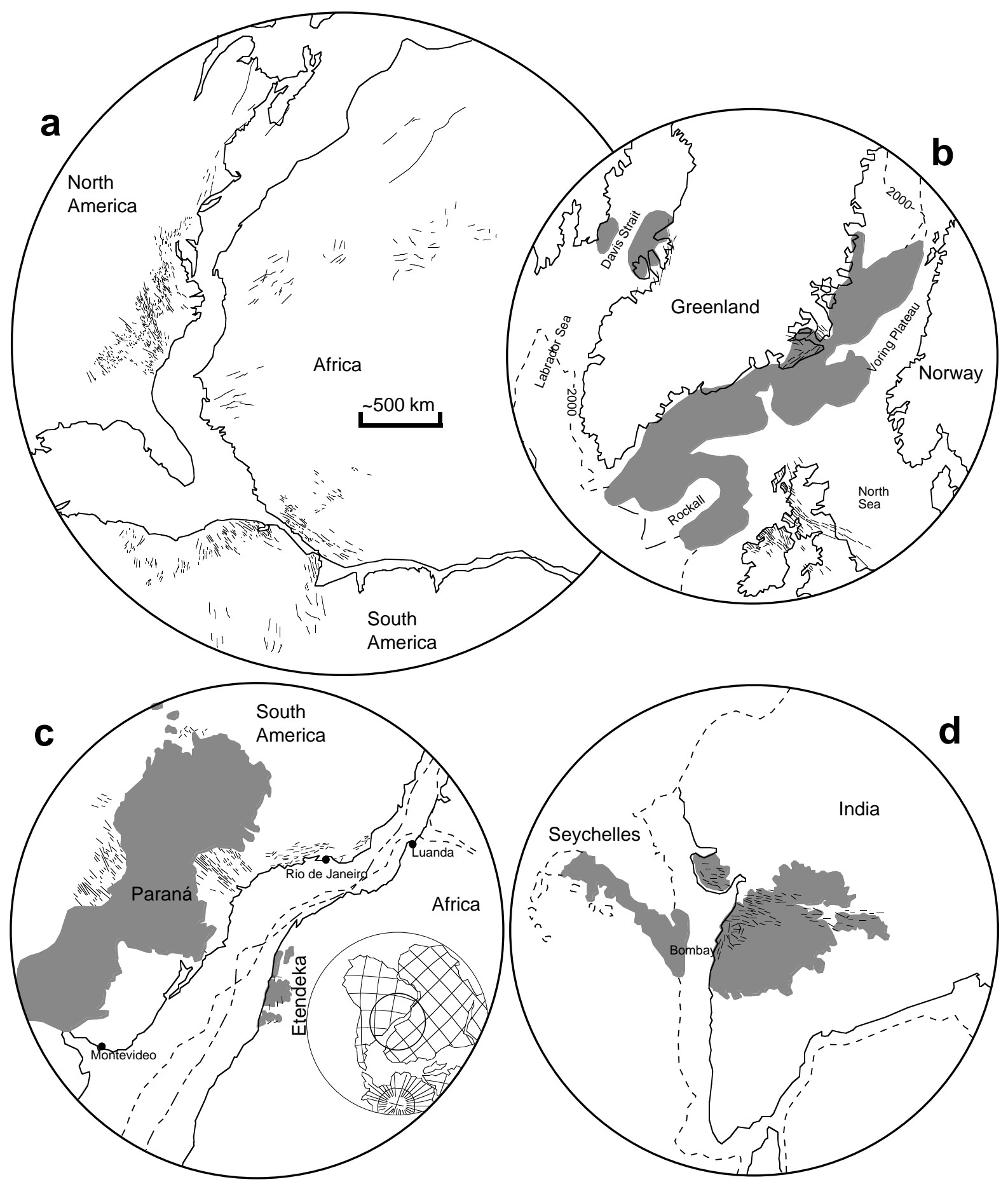

Figure 5. a) Pre-drift reconstruction of the Atlantic Ocean, showing the schematic geometry of CAMP-related dikes. Simplified from McHone [2000]. Diameter of circle is approximately $4000 \mathrm{~km}$. b) Reconstruction of northern North Atlantic at $55 \mathrm{Ma}$, showing extent of Tertiary Igneous Province (gray) emplaced during breakup and known extent of dikes of same age. c) Reconstruction of the South Atlantic at $120 \mathrm{Ma}$, showing extent of Paraná flood basalt and Etendeka igneous province (gray) and known dikes of similar age. d) Reconstruction of the Indian-Seychelles region at $\sim 65 \mathrm{Ma}$, showing extent of Deccan plateau basalts and related igneous activity (gray), and dikes of similar age. Parts (b), (c), and (d) are modified from White [1992], use a Lambert stereographic projection, and encompass areas with diameters of $3000 \mathrm{~km}$, approximately the same scale as (a). 


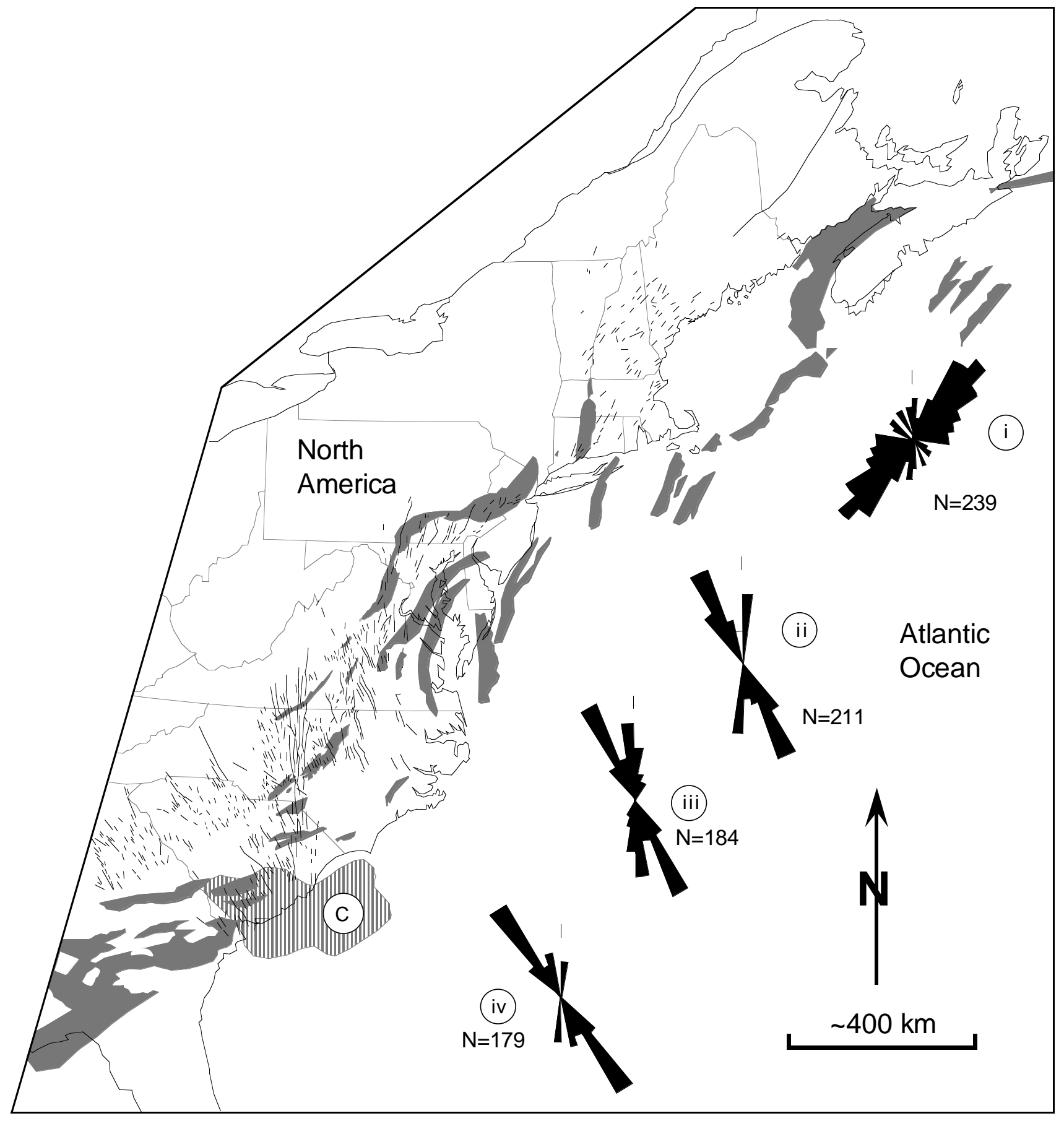

Figure 6. Early Jurassic-age diabase dikes (thin black lines) in eastern North America. Rift basins are stippled. C = possible extent of Clubhouse Crossroads Basalt [Oh et al., 1995]. Rosettes indicate dike orientations (small tick marks indicate north) for the following regions: (i) Maritime Canada, New England, and New Jersey; (ii) Pennsylvania, Maryland and Virginia; (iii) North Carolina; (iv) South Carolina and Georgia. Modified from McHone [1988]. 

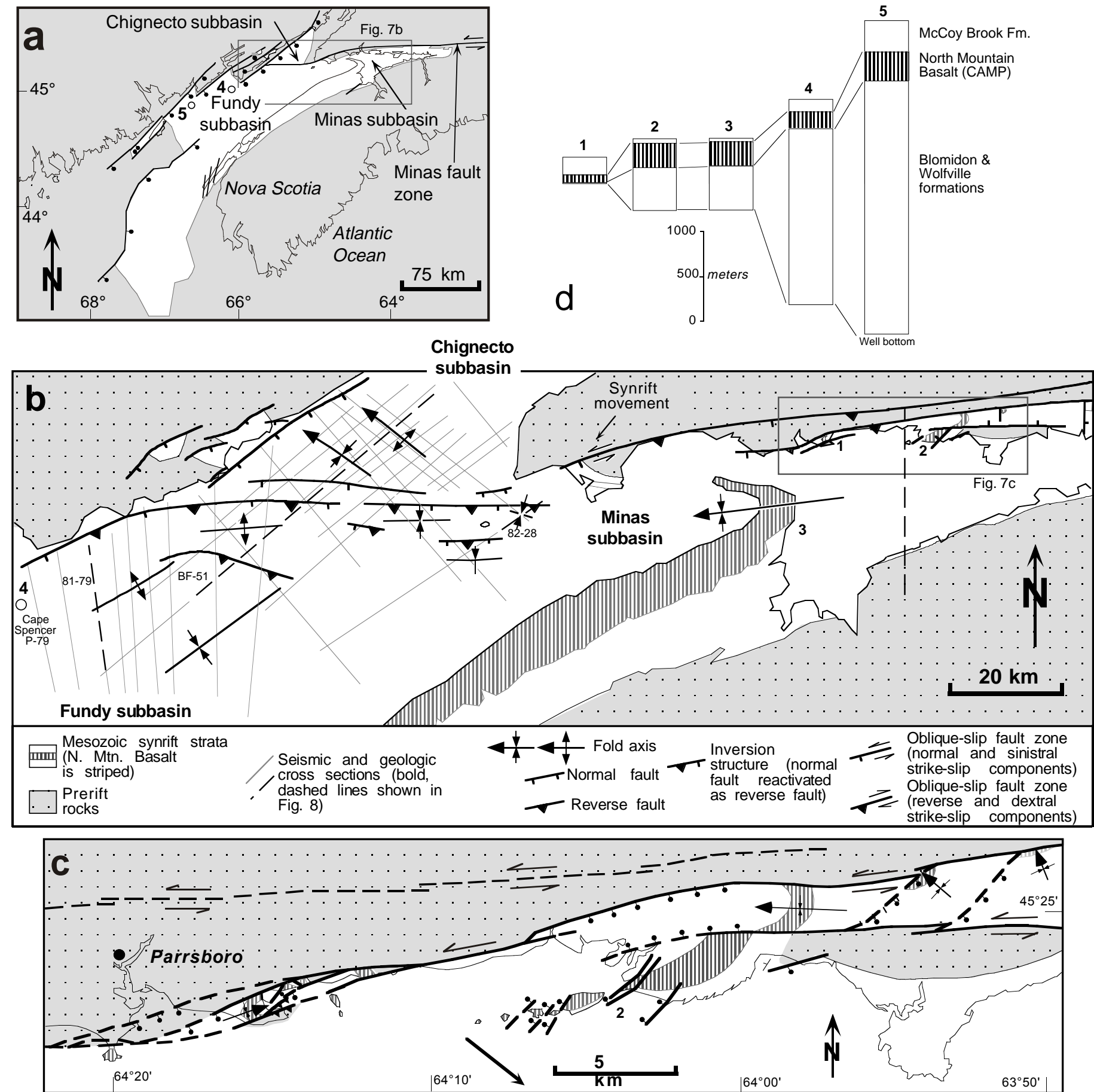

Figure 7. Maps and stratigraphic sections of the Fundy basin, Canadian Maritimes [from Olsen and Schlische, 1990; Withjack et al., 1995]. a) The Fundy basin consists of the NE-trending Fundy and Chignecto subbasins and the E-trending Minas subbasin. b) Geologic map of part of the Fundy basin showing faults and folds related to extension and inversion and locations of seismic lines and cross section in Figure 8. c) Geologic map of the part of the northern margin of the Minas subbasin showing two sets of faults: ENE- to E-striking faults with oblique motion and NE-striking faults with mostly dip-slip motion. Arrow indicates extension direction. Only fault motions associated with exten-sional phase are shown in (a) and (c). d) Stratigraphic sections from five locations in the Fundy basin; see numbers in (a), (b), and (c). 

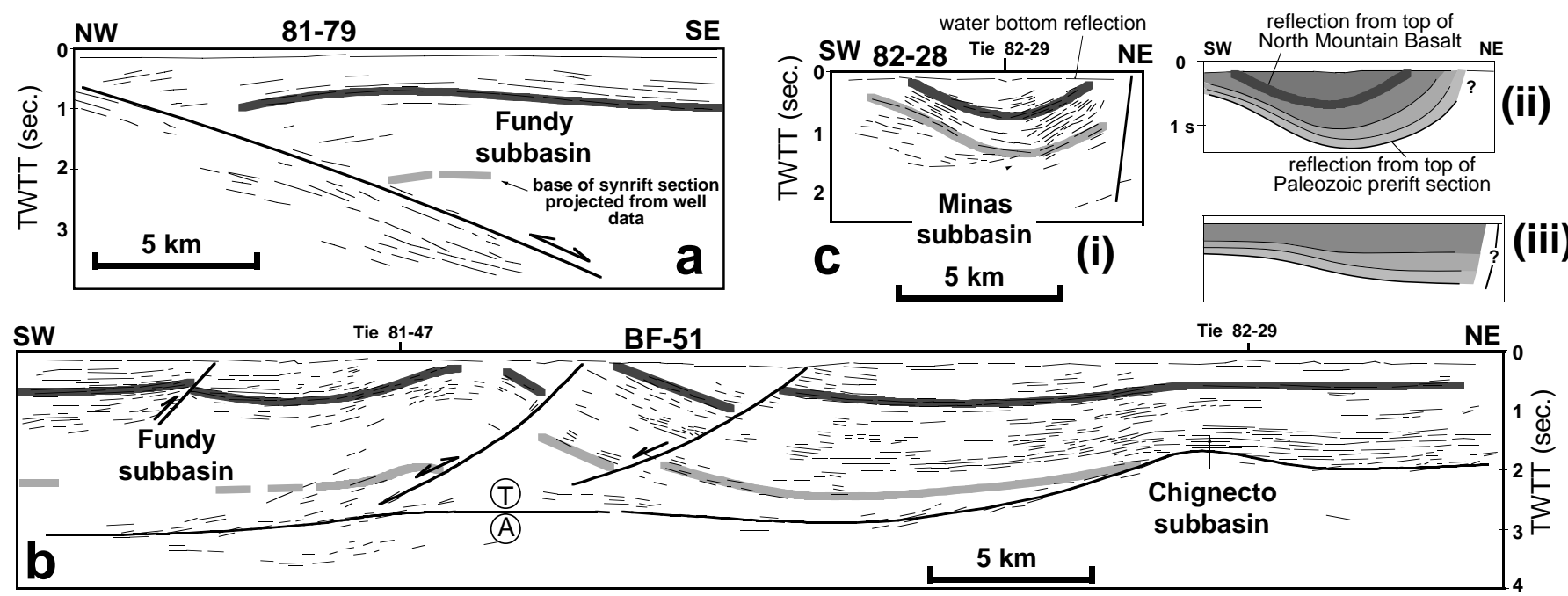

BF-51

Tie $82-29$

NE 0
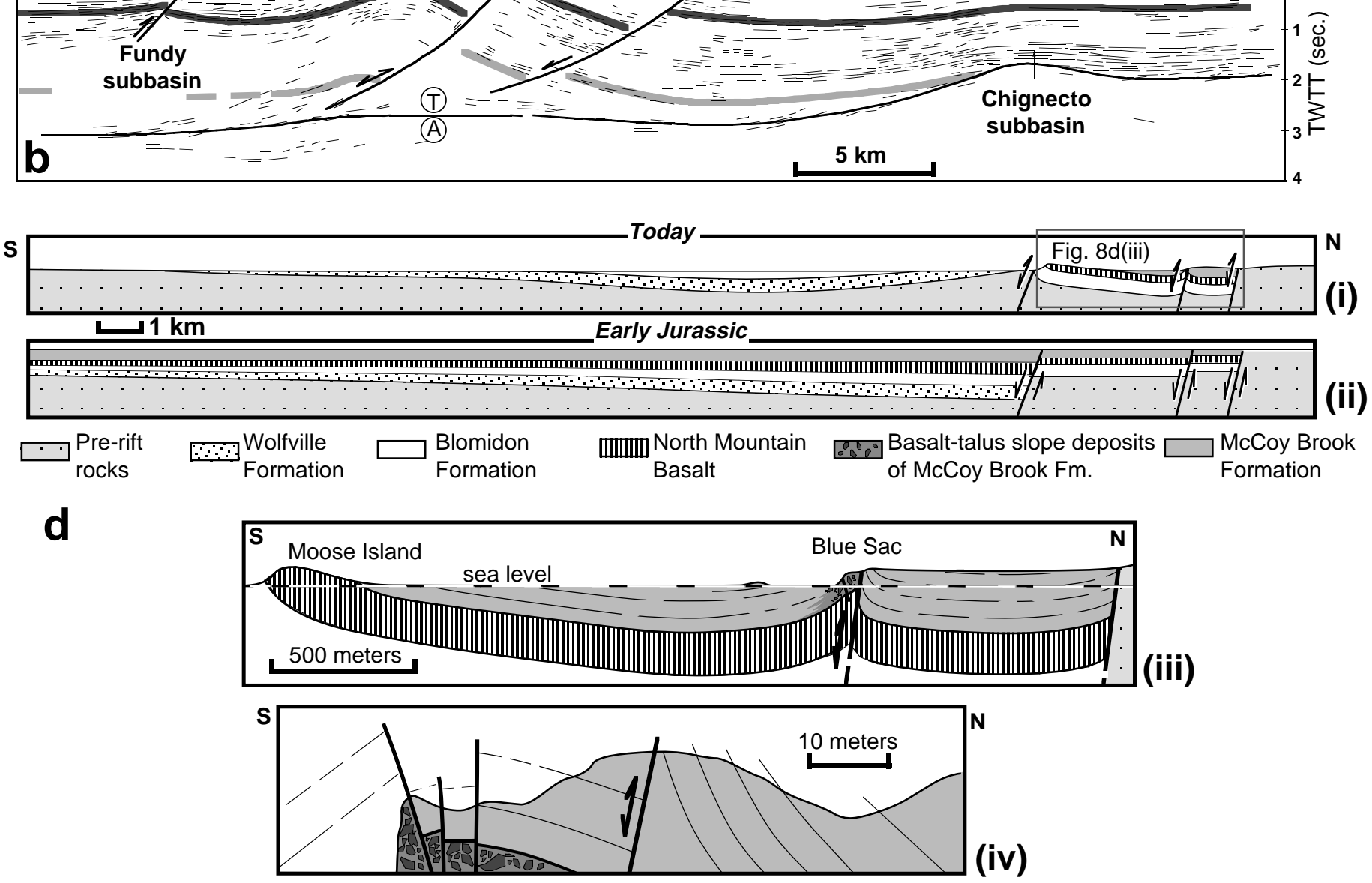

Figure 8. Selected interpreted seismic reflection profiles and cross sections from the Fundy basin. The seismic lines show the variation in the geometry of inversion-related folds: a) broad anticlines above gently dipping faults (81-79), b) tighter anticlines above moderately dipping faults (BF51), and c) tight synclines adjacent to steeply dipping faults (82-28). Light-shaded line marks base of synrift section; dark-shaded line marks reflection from North Mountain Basalt. T, movement toward viewer; A, movement away. For 82-28 (c), (i) shows the line drawing of the seismic data, (ii) shows the geological interpretation, and (iii) shows the pre-inversion geometry. Note that units thicken toward the boundary fault but do not thicken toward the axis of the inversion syncline. d) Regional geologic cross section through the Minas subbasin today (i), showing inversion-related folds, and during Early Jurassic deposition (ii). (iii) Cross section at Blue Sac with central anticline and surrounding synclines. Basalt-talus slope deposits occur only in hanging wall, suggesting that the hanging wall was downthrown during deposition and upthrown after deposition. (iv) Sketch of outcrop at Blue Sac showing high-angle fault with reverse separation and steeply dipping beds of McCoy Brook Formation. Most faults have strike-slip as well as dip-slip displacement. Modified from Withjack et al. [1995]. 

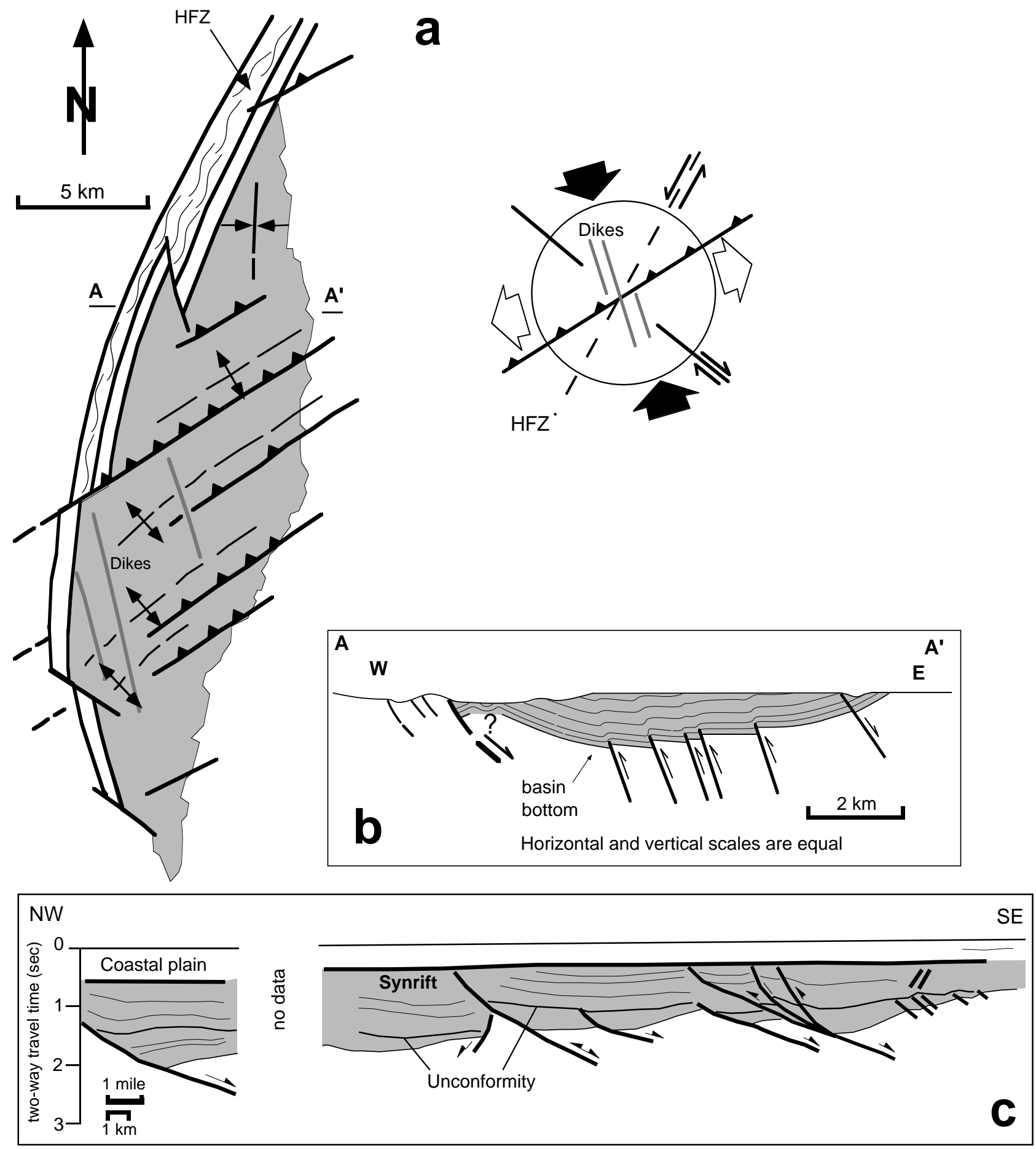

Figure 9. Geology of the Richmond and Taylorsville basins. a) Structural sketch map of the Richmond basin showing NNW-trending dikes cross-cutting NE-trending folds. Inferred shortening direction (black arrows) is based on contractional structures. HFZ is the Hylas fault zone. Modified from Venkatakrishnan and Lutz [1988]. b) Cross section of the Richmond basin showing basement-involved reverse faults and fault-propagation folds. Modified from Shaler and Woodworth [1899] and Withjack et al. [1998]. c) Interpreted seismic line across the Taylorsville basin, showing inverted faults and inversion-related folds. Simplified from LeTourneau [1999]. 


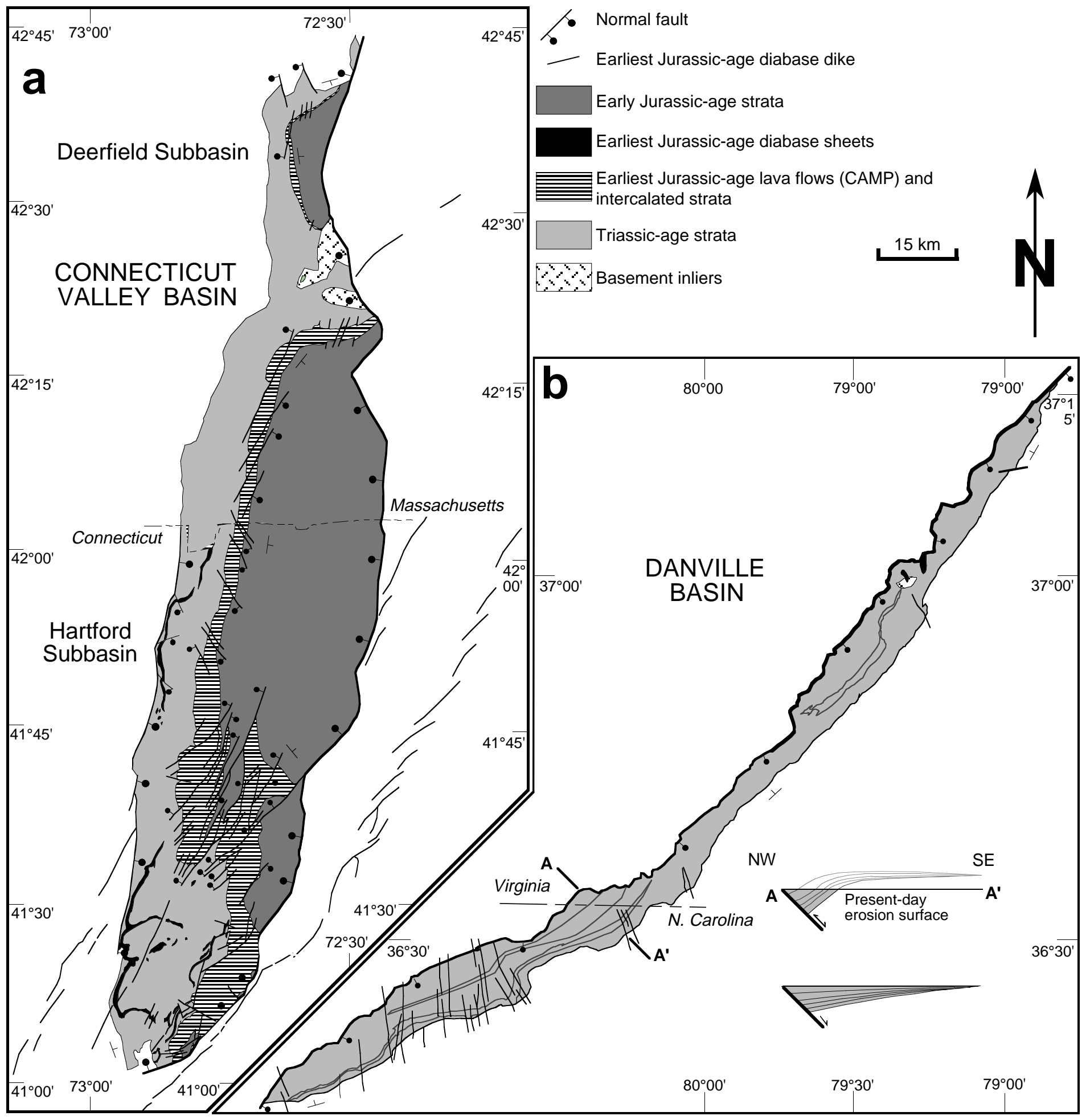

Figure 10. Geologic maps of (a) the Connecticut Valley basin (Connecticut and Massachusetts) and (b) the Danville basin (North Carolina and Virginia). Near the Connecticut Valley basin, earliest Jurassic diabase dikes are northeast trending and subparallel to the regional trend of the basin. Near the Danville basin, earliest Jurassic diabase dikes are north and northwest trending and are subperpendicular to the regional trend of the basin. Early Jurassic lava flows and sedimentary rocks are present in the Connecticut Valley basin, but are absent in the Danville basin. Danville basin cross section (top) shows inferred inversion-related geometry (see Figure $4 \mathrm{c}$ for experimental analog) and restored basin geometry prior to inversion (bottom) (assuming that the width of the Danville basin was approximately the same as the present-day width of the Connecticut Valley basin). Modified from Schlische [1993] and Ackermann et al. [2002]. 


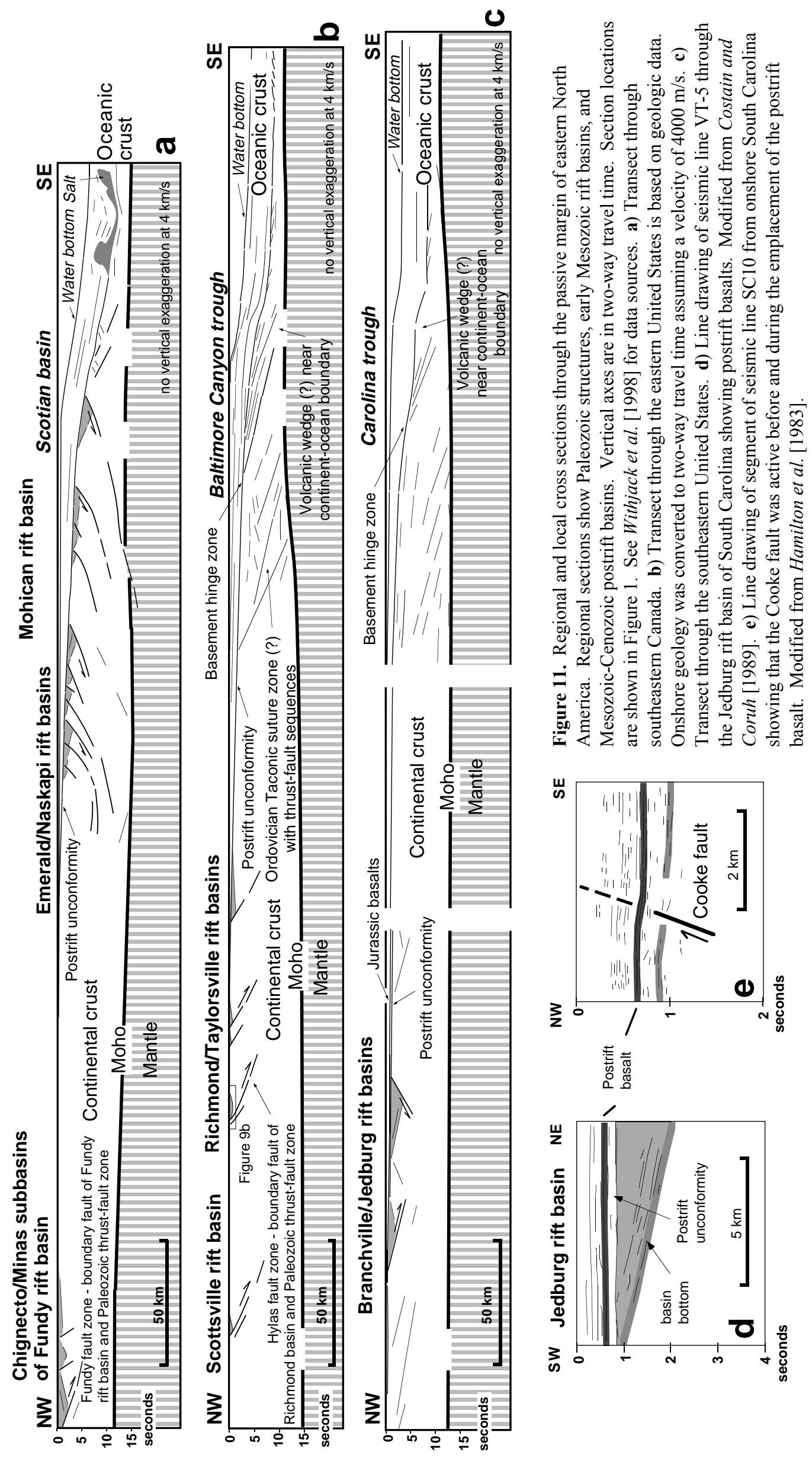




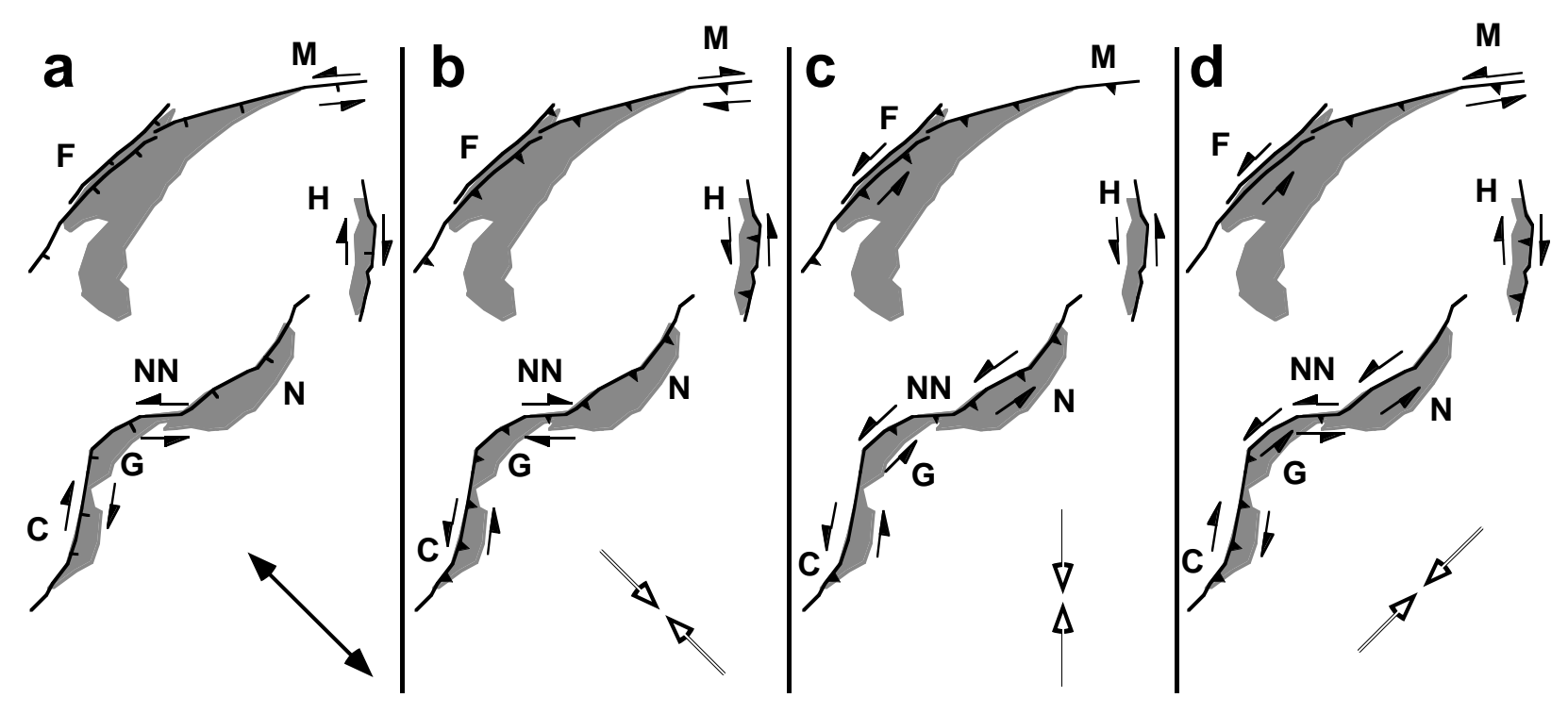

Figure 12. The extension direction and shortening direction acting on variably oriented preexisting zones of weakness affect the type of fault reactivation. Each panel shows the present-day configuration of the boundary faults and synrift strata for the Culpeper (C), Gettysburg (G), Narrow Neck (NN), Newark (N),

Hartford-Deerfield (H), Fundy subbasin (F) and Minas subbasin (M) of the Fundy basin, and the inferred type of fault reactivation for a) NW-SE extension, b) NW-SE shortening, c) N-S shortening, and d) NE-SW shortening. Because the shortening direction associated with basin inversion is not well constrained, three possibilities are shown here. Each possible shortening direction predicts different types of faulting along the boundary faults of the rift basins. For example, NE-SW shortening predicts reverse slip along the Newark basin and Fundy subbasin border faults and reverse-right-oblique slip along the Minas subbasin and Narrow Neck border faults. In contrast, NW-SE shortening predicts reverse-left-oblique slip along the Newark and Fundy subbasin border faults and reverseslip along the Minas subbasin and Narrow Neck border faults. 

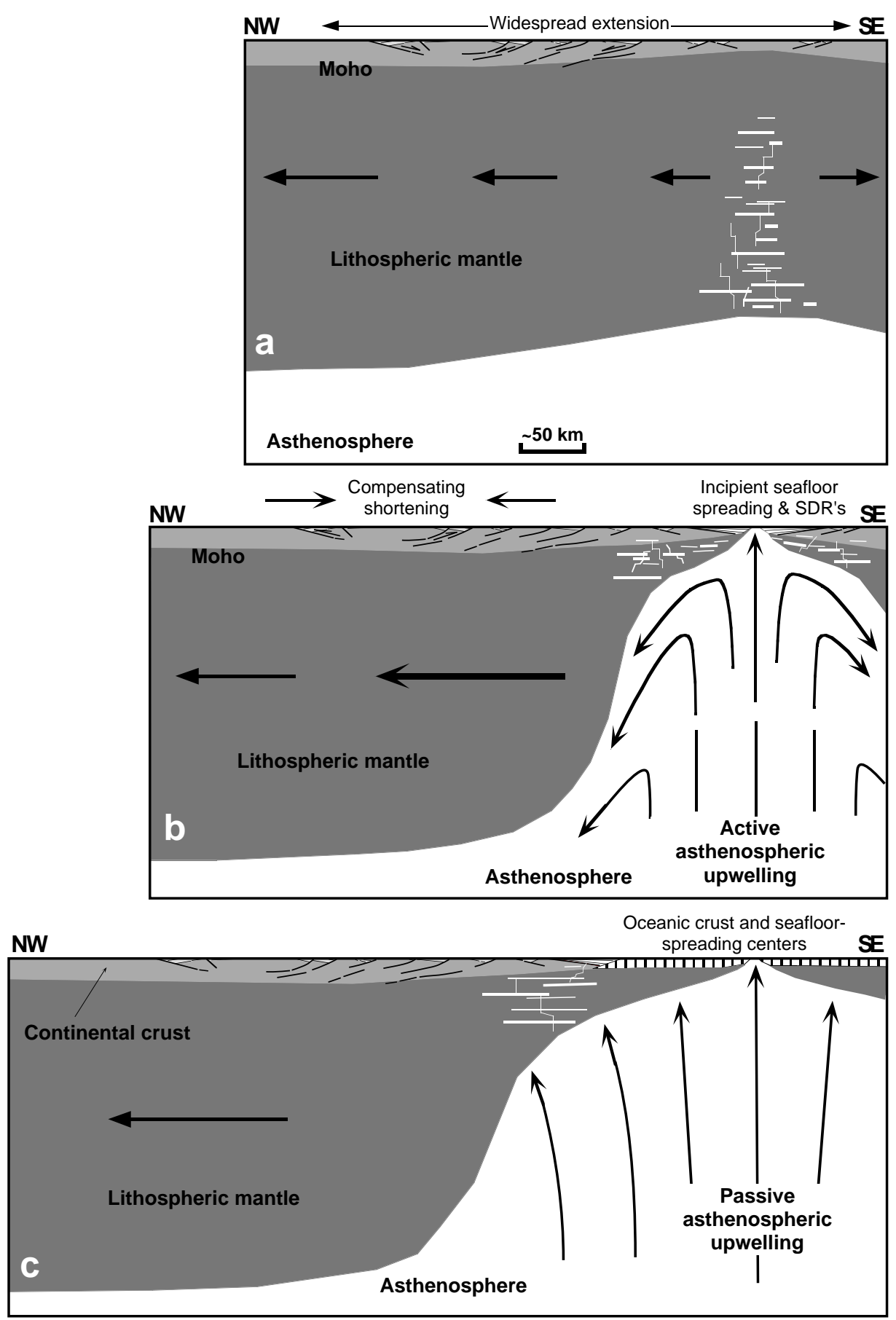

Figure 13. Tectonic model for central eastern North America. a) Early rifting. Distant plate-tectonic forces produce divergent lithospheric displacements. b) Late rifting. Lithosphere is substantially thinned. Gravitational-body forces and traction forces associated with the hot, low-density asthenospheric upwelling increase substantially. In response,

lithospheric displacements near the upwelling exceed those far from the upwelling, causing shortening (inversion) in the intervening zone. c) Early drifting. Lithospheric displacements far from upwelling increase, eventually equaling those near the upwelling. Most shortening/inversion ceases, and the asthenospheric upwelling becomes passive. From Withjack et al. [1998]. 